
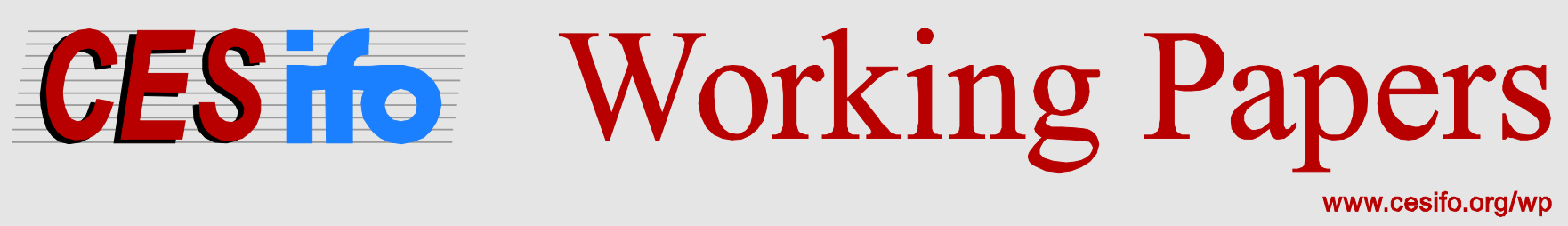

\title{
Modelling the Egyptian Shadow Economy: A Currency Demand and A MIMIC Model Approach
}

\author{
Mai Hassan \\ Friedrich Schneider
}

CESIFO WORKING PAPER NO. 5727

CATEGORY 1: PUBLIC FINANCE

JANUARY 2016

An electronic version of the paper may be downloaded

- from the SSRN website:

- from the RePEc website:

- from the CESifo website:

www.SSRN.com

Www.RePEc.org

www.CESifo-group.org/wp 


\title{
Modelling the Egyptian Shadow Economy: A Currency Demand and A MIMIC Model Approach
}

\begin{abstract}
We estimate the size and trend of the Egyptian shadow economy using two of the most common methods: the currency demand approach and the structural equation MIMIC model. To the best of our knowledge, this is the first comprehensive study to estimate the size of the shadow economy in Egypt during the last four decades (1976 to 2013). In addition to the standard explanatory variables used in the currency demand approach and MIMIC model, we consider variables that are specifically related to the Egyptian economy such as self-employment, agricultural importance and a proxy for institutional quality of democratic institutions. Our results indicate a decreasing trend of the size of the shadow economy from more than $50 \%$ in 1976 to $32 \%$ in 2013, yet it still comprises a large portion of the official GDP.
\end{abstract}

JEL-codes: C320, H260, I200, O170, P480.

Keywords: shadow economy of Egypt, currency demand approach (CDA), MIMIC estimation.

Mai Hassan

Center of Near and Middle Eastern Studies (CNMS), Department of Middle East Economics, University of Marburg

Deutschhausstraße 12

Germany - 35032 Marburg mai.hassan@staff.uni-marburg.de
Friedrich Schneider

Department of Economics

Johannes Kepler University Linz

Altenbergerstraße 69

Austria - 4040 Linz

friedrich.schneider@jku.at

January, 20th 2016, Preliminary draft

Accepted for presentation at the European and US Public Choice Meetings, March and April 2016. Comments and suggestions are highly welcomed. Presented at the Shadow2015 Conference, Exeter, UK, July 2015. 


\section{Introduction}

Most countries around the world have sizeable shadow economies, particularly in the developing world. The shadow economy has diverse effects on the country's social and economic life which threaten the country's stability and growth prospects (Schneider and Enste, 2013; Barbosa et al.2013; Dell'Anno, 2007). Therefore, a general interest in understanding the shadow economy increased throughout the years. However, reaching a unified definition is still an unresolved issue. For the purpose of this study, the adopted definition is that the shadow economy involves all currently unrecorded economic (market-based) activities which, if registered, would contribute to the officially calculated national income (GDP). Since the focus of this paper is on the productive economic activities that are usually included in the national accounts, this definition excludes illegal activities such as criminal activities, human trafficking, or smuggling. Also, undeclared activities such as charitable, household or Do-it-Yourself activities are excluded because such activities are not normally included in the national accounts statistics (Schneider et al., 2010).

In the aftermath of the 2011 revolution, policy makers are working with economic planners to execute major reforms to promote economic development and stabilize the political system in Egypt. Amongst the objectives of these reforms is tackling the shadow economy. However, the current government efforts to fight the shadow economy by police and other legal measures are limited. Their approach is either to evacuate street vendors by brutal police force or to intensify regulations by increasing jail times from 1 month to 3 months and penalties from $1000 \mathrm{LE}$ to 5000 LE for involvement in informal economic activities. Needless to say, these efforts have backfired by creating rising instability. Not only that, but also, the more recent initiatives to license street vendors have failed to regulate the shadow economy. Therefore, knowledge on the size and development of the Egyptian shadow economy becomes essential for policymakers to have a coherent plan of reforms and policies to formalize the shadow economy in order to be able to restore fiscal stability and drive economic growth. Until today not much research has been done to analyze and econometrically estimate the Egyptian shadow economy over a long period of time.

The present study adds to the literature an understanding of the evolution of the shadow economy in Egypt from 1976 to 2013. To the best of our knowledge, this is the first comprehensive study 
to apply the Currency Demand Approach as well as the MIMIC model to estimate the size of the shadow economy in Egypt. A few studies, which are shown in table (1.1), investigating the shadow economies around the world have also included Egypt. They show a wide range of the size of the Egyptian shadow economy. Yet, these studies were done using a general cross section analysis for shorter periods of time. Additionally, they do not take into account the specific social, economic and political structures that significantly influence the Egyptian shadow and official economy.

Our paper is organized as follows. In section 2, a brief background on the Egyptian economy is provided. In section 3, we present the MIMIC and CDA models to estimate the size of the shadow economy as well as our results. In section 4, an analysis of the shadow economy and policy implications are undertaken. Finally, in section 5 a short summary is given and conclusions are provided.

Table 1.1: Previous estimates of the Egyptian shadow economy

\begin{tabular}{|c|c|c|}
\hline Author(s) & Method & SE \% of GDP \\
\hline $\begin{array}{c}\text { Schneider and Enste (2000) } \\
\text { (Table 4 page 100) from } \\
\text { Lacko (1996) table 18 }\end{array}$ & Physical Input Method & Average 1989-1999:68\% \\
\hline & & $2000: 35.1 \%$ \\
\hline $\begin{array}{c}\text { Schneider (2005) } \\
\text { (Table 2 page 118) }\end{array}$ & Dynamic Panel MIMIC model & $2002: 36 \%-2003: 36.9 \%$, \\
\hline $\begin{array}{c}\text { Schneider et al. (2010) } \\
\text { (Table 3.3.2 page 23) }\end{array}$ & Dynamic Panel MIMIC model & $1999: 35.4 \%-2006: 36.7 \%$ \\
\hline $\begin{array}{c}\text { Alm and Embaye (2013) } \\
\text { (Appendix page 534) }\end{array}$ & Dynamic Panel CDA & $1984: 48.7 \%-2006: 30.4 \%$ \\
\hline
\end{tabular}

Source: see column 1 "Author(s)"

\section{The Egyptian Economy: Some Background Information}

To provide the reader with a better understanding of the Egyptian economy, we briefly examine the Egyptian economy since the early 1970s to the most recent time (2013). The Nasser's era began when the former President Gamal Abd EL-Nasser overthrew King Farouk and became the first president of Egypt from 1956 to 1970. The highlight of Nasser's regime was a massive expansion of the public sector in order to achieve substantial industrialization through expanding the role of the state. Nasser was a humanitarian socialist who launched a nationalization program 
to increase the role of the state in the economy. His nationalization program started with a major land reform in 1952, in which land ownership was redistributed to the poor and small farmers in order to benefit them and to increase their landownership so as to increase their income and standard of living. Following the land reform, in 1956 the nationalization of the Suez Canal was another big policy measure by Nasser. The goal behind the nationalization of the Suez Canal was to take over the profits of the canal and to finance the construction of the Aswan Dam. It is important to note that the nationalization program led by Nasser's regime did not stop with the Suez Canal, but he nationalized all commercial banks, insurance companies, and shipping companies. The state also took control over major pharmaceutical companies and heavy industries such as construction companies. Nasser's goal was to build a social, planned economy in order to serve a great majority and to achieve a fair income distribution among all levels of the economy. In an attempt to achieve a fair income distribution, high marginal tax rates on high income earners were imposed along with major subsidization of food (bread) and fuel commodities. During Nasser's era, the public sector was the primary employer to the extent that each university graduate was guaranteed a job in the public sector which was part of his First Five year Plan (1960-1965) of reform in which the state took major control over the economy. However, Nasser's nationalization program did not succeed and by the end of 1965 the country faced major economic problems due to the misallocation of resources and inefficiencies of the state controlled enterprises. As a result, Egypt had to negotiate a financial loan form the IMF. This deal with the IMF forced Egypt to devalue its local currency by $40 \%$, to raise prices, and to increase taxes. It is evident from the national statistics that in this era total tax revenues were amongst the highest during the period of our study. The Nasser's era ended by his death and the unfulfilled promises to the extent that the country suffered from instability, high prices and taxes.

After Nasser's death, Anwar El-Sadat, the vice president at that time, took over the presidency from 1970 to 1981. Sadat did not follow the footsteps of Nasser's regime, yet he had another vision for Egypt's economy. During the first years of Sadat's presidency, nothing has changed much in terms of economic reform, but Sadat made it clear that the president has the sole authoritarian power and he got rid of the vice president and the security elite. Until 1973 Sadat demonstrated his political power and Egypt continually suffered from an inefficient public sector, rising debt levels and a stagnant private sector. The first major event was the victory of the 1973 war which restored some of the pride that was lost in the defeat in the 1967 war. However, the 
1973 war was financially costly as military funding was strongly rising. The state financed the military expenditures by increasing taxes and state controlled prices. In return, Sadat had to respond and announced the Open Door economic reform of 1974. The Open Door policy aimed at increasing foreign investment and technology transfer in order to achieve economic growth. Labor markets were relaxed as Egyptians could freely work abroad and foreigners were encouraged to invest in Egypt. Liberalization, under the Open Door policy, favored mostly the wealthy elites Egypt, e.g. by granting major tax exceptions and marginal tax reductions. However, the economic performance did not prosper under the Open Door policy. The majority of private funds were spent in tourism investments, private luxury construction projects and the financial industry. Little was directed to industrialization and the total industrial activity declined. Due to the increasing population size consumption continued to increase, however, output levels were stagnating. Even though exports were rising, imports on the other side were soaring especially for food commodities and luxury products. As a result, a huge gap between consumption and production and another gap between imports and exports led the country to a financial crisis. In return, this financial crisis had to be financed by external borrowing from the Gulf States and the IMF. Sadat's era ended by his assassination by the Muslim Brotherhood in 1981 and he left behind him a country with a badly-functioning economy because from his liberalization policies only a few elites benefited.

From 1981 to 2011, Egypt was under the rule of Hosni Mubarak. Mubarak faced a challenging era as the nationalization vision of Nasser and the liberalization led by Sadat failed to stimulate economic growth. By the time Mubarak took office, the Egyptian economy was mainly dependent on the Suez Canal revenues, on remittances from Egyptians working abroad and, most importantly, on foreign aid. Also, the public sector was still the dominant one compared to the private sector in Egypt. In response to that, Mubarak launched the First Five year plan of reforms in 1982. The aims of this five year plan were to increase local industrial activity by imposing tariff barriers to protect domestic industries, lower interest rates on industrial loans and lower taxes on industrial projects. These policies helped the industrial sector to grow. Further down the road, in 1991, Egypt signed agreements with the IMF and the World Bank to receive external funding and aid. It is important to note that foreign aid resulted in economic growth in Egypt. Along with growth in industrialization and the manufacturing sector, the role of the dominating 
agricultural sector decreased over time. The role of the private sector increased due to an attempt to increase privatization of the state-owned companies in order to strengthen industrialization.

Even though Egypt experienced some prosperity in terms of foreign investment, the increasing population and low human education development impeded major economic development. Egypt still suffered from a poor uneducated population with increasing unemployment, poverty levels as well as income inequality. Moreover, Egypt suffered from an autocratic government with a highly regulated economy. In 2011, the Egyptians marched in the streets to speak out loudly for more freedom and democratic rights. Additionally, they demanded a better performing economy that is characterized by a market economy and democracy. Hence, the Egyptians revolted against the 30-year bureaucratic and dictatorial system that has led to the resignation of the former president Hosni Mubarak. Since the 2011 revolution, Egypt has been suffering from political and economic instability. Unemployment increased as people were laid off because companies were closing either internationally or nationally, political instability increased due to the continuous street revolts and foreign investment decreased due to the political and economic instability that the country suffered from. Nowadays, the current president Abdel Fatah El-Sisi tries to implement major economic reforms to restore economic stability. One of the major accomplishments until today is the Suez Canal widening project aiming to increase revenues and to restore confidence in the investment climate in Egypt (Nagarajan, 2013).

\section{Modelling the Egyptian Shadow Economy}

In the literature there are various methods to measure the size and trend of the shadow economy over time, yet it is still a difficult task due to the nature of the shadow economy of being untraceable and unrecorded. Those methods are divided into direct, indirect and model approaches ${ }^{1}$. For the case of Egypt, we apply two of the most widely used approaches to estimate the size of the shadow economy. Due to the complex nature of the shadow economy and since there is no consensus in the literature on which method is better, we use the following two: The first one is based on the Structural Equation Model known as the Multiple Indicator Multiple Causes (MIMIC) Model, while the second one is based on the Currency Demand Approach (CDA).

\footnotetext{
${ }^{1} \mathrm{~A}$ brief description is given in the appendix (A1).
} 


\subsection{Structural Equation (MIMIC) model}

Formally, the MIMIC model has two parts: the structural model and the measurement model ${ }^{2}$. The structural model shows that the latent variable $\eta$ is linearly determined by a set of exogenous causal variables which can be illustrated as follows:

$\eta=\gamma^{\prime} \chi+\varsigma$

where $\chi$ is a vector of causal variables, $\gamma$ is a vector of scalars, $\eta$ is the latent variable (shadow economy) and $\varsigma$ is a structural disturbance term.

The measurement model which links the shadow economy with the set of selected indicators is specified by:

$y=\lambda \eta+\varepsilon$

where $\gamma$ is a vector of indicator variables, $\lambda$ is a vector of loading factors to represent the magnitude of the expected change for a unit change in the latent variable $\eta$. The $\varepsilon$ is the measurement error term.

The MIMIC approach considers various causes that influence the development of the shadow economy and also considers multiple traces over time. There is a large body of literature providing a theoretical explanation of the causal and indicator variables, which directly influence the size and development of the shadow economy over time. However, those variables differ from country to country. For Egypt, the causal variables are discussed in the following.

\subsubsection{Causal variables}

\section{i. Tax burden}

The most widely accepted and important cause affecting the size of the shadow economy is the tax burden. Numerous empirical studies confirm a statistically significant effect of the tax burden on the shadow economy. Among others are Schneider (2010) for 21 OECD countries, Tanzi (1999), Alanon and Go'mez (2005) for the Spanish shadow economy and Buehn (2012).

\footnotetext{
${ }^{2}$ For a brief description of the MIMIC model specification, we refer to the appendix (A1.2)
} 
The tax burden is of major interest to economists because taxes influence the labor-leisure choices and stimulate labor supply in the shadow economy. The higher the difference between total costs of labor in the formal economy and net income, the stronger the incentives to operate in the shadow economy in order to evade paying those taxes (Loayza, 1996; Schneider, 2005). Additionally, the tax burden increases the production costs of goods and services which increase their price in the formal market. Therefore, firms operating in developing countries like Egypt have higher incentives to engage in informal activities in order to evade taxes and to reduce production costs to be able to sell their products at lower prices given the competition in the shadow and official economy. In the econometric analysis, the tax burden is measured by the share of total tax burden to GDP.

Hypothesis 1: The higher the tax burden, the larger the size of the shadow economy is, ceteris paribus.

\section{ii. Institutional quality of democratic institutions}

It is quite important to analyze the effect of the quality of public institutions on the size and development of the shadow economy. Good rule of law, by securing property rights and enforceability of contracts, increases the benefits to remain in the official economy and increases the costs of informality. On the other hand, corruption of bureaucracy and public servants along with a weak rule of law are associated with large shadow economies (Schneider, 2010).

Various authors have studied the quality of public institutions as a determining variable of the shadow economy. Based on a study of 21 OECD countries, Schneider (2010) found out that the quality of institutions is statistically significant affecting people's incentives to operate in the shadow economy. Razmi et al. (2013) also concluded a statistically negative relationship between the quality of institutions and the size of the underground economy in OIC countries.

As an approximation of institutional quality, we use a variable measuring the quality of democratic institutions, namely the Polity IV index. Recent studies by various scholars highlighted the negative relationship between democracy and the size of the shadow economy. Teobaldelli and Schneider (2013) confirmed a negative relationship between democracy and the size of the shadow economy. Also, Solomon and Schrestha (2014) concluded that a high degree of democracy reduced the informal economy in Nepal by $10 \%$. In many developing countries 
mistrust in the government and inadequate democratic institutions providing poor and inefficient public goods and services influence people's incentives to operate in the shadow economy (Petersen et al., 2010).

To capture this effect, the PolityIV index is used as a proxy of the quality of democratic institutions. The PolityIV index ranges from -10 to +10 , representing autocratic to democratic states, respectively. Hence, the higher the score, the better is the quality of institutions representing the extent of democratic institutions in a country. We expect a negative sign associated with this variable.

Hypothesis 2: The better the quality of democratic institutions, the smaller the size of the shadow economy is, ceteris paribus.

\section{iii. Size of the agricultural sector}

The importance of the agricultural sector plays a significant role in affecting the size and development of the shadow economy. Vuletin (2008) concluded that the dominance of the agricultural sector has a significant effect on the size of the shadow economy in Latin America and the Caribbean. Similarly, almost $45 \%$ of the agricultural sector in Jamaica is conducted informally (Wedderburn et al., 2011). Also, countries like Yemen and Morocco have high levels of informality due to the large share of agricultural employment relative to total employment (Angel-Urdinola and Tanabe, 2012). It is argued that informality is segmented by sectors with clear dominance of the agricultural and related sectors. The reason behind the concentration of informal work in the agricultural sector is the weak control and governance capacity of the local government, especially in rural areas which in return creates the perfect environments for shadow economic activities. The agricultural sector is difficult to regulate which indicates that the higher the importance of this sector, the larger is the shadow economy (Vuletin, 2008).

In many studies, agriculture is excluded from the measurement of the size of the shadow economy. However, the majority of informal employment and work can be concentrated in agriculture, especially for developing countries (Chen, 2007). Therefore, for the first time we include this variable as a causal factor of the shadow economy which is highly relevant to the case of Egypt since the agricultural sector plays a significant role in the Egyptian economy. Egypt has an agricultural sector based on its climate, landscape and geographical location on the 
river Nile. Using statistics, agricultural employment in Egypt is larger compared to employment in the industrial sector. In 1980, employment in agriculture reached $42 \%$ compared to $20 \%$ employment in the industrial sector. The share of agricultural employment continued to be larger throughout the years, reaching in $199438 \%$ compared to $22 \%$ in industry, 32\% in 2007 compared to $22 \%$ and $30 \%$ in 2011 compared to $24 \%$ in the industrial sector. In the MIMIC model the agricultural value-added as \% of GDP is used to reflect the importance of the agricultural sector in Egypt.

Hypothesis 3: The more dominant the agriculture sector, the larger the size of the shadow economy is, ceteris paribus.

\section{iv. Unemployment rate}

Despite a large literature, the causal relationship between unemployment and the shadow economy is still ambiguous. The widely accepted hypothesis is that an increase in unemployment leads to an increase in shadow economy activities because unemployed people have a strong incentive to find jobs in the informal economy. Thus, the expected sign for the effect of unemployment on the shadow economy is positive. Schneider et al. (2010) concluded that the unemployment rate plays a significant role in affecting the size of the shadow economies in Transition countries as well as in the High Income OECD countries. The same conclusion had been made by Dell'Anno et al. (2007) for the cases of Spain, Greece and France. However, it is counter argued that the availability of informal jobs becomes limited when there is a contraction in the overall economy and when unemployment remains very high, because the availability of jobs, either formal or informal, decreases. Based on their findings, Alanon and Go'mez-Antonio (2005) as well as Macias and Cazzavillan (2010) concluded that the unemployment rate is a significant factor that negatively influences the size and development of the shadow economy in Spain and Mexico, respectively. Also, Buehn and Schneider (2008) concluded that unemployment, in the long run, has a negative effect on the French shadow economy. With reference to the overwhelming evidence, we argue that there is a positive relationship between unemployment and the shadow economy.

Hypothesis 4: The higher the unemployment, the larger the size of the shadow economy is, ceteris paribus. 


\section{v. Self-Employment}

As another independent variable we added the self-employment quota as causal factor affecting the development of the shadow economy in Egypt. With reference to the literature, the rate of self-employment as a percentage of the labour force in the official economy is regarded as a cause of the shadow economy. The theoretical assumption is that the self-employed are highly motivated to avoid complying with tax regulations because they have a great number of legal and "illegal" tax deductions. Also, they enjoy direct business relationships with the customers, which allows them to bargain with their customers to reach a "tax saving" agreement. Last, the selfemployed are more inclined to employ irregular and informal employees because they have fewer and lesser auditing controls relative to bigger and formal organizations. Given the economic status in Egypt, in which the private sector grew only by 5\% in 12 years, and the abundance of labor, the formal economy can't absorb the increasing number of the self-employed which "drives" them to turn to the shadow economy. Therefore, the expected sign of this variable is a positive sign. Studies by Dell'Anno et al. (2007) and Tedds (2005) found evidence to support the positive relationship between self-employment and the shadow economy.

Hypothesis 5: The higher the self-employment rate, the larger the size of the shadow economy is, ceteris paribus.

\subsubsection{Indicators}

After considering various causes influencing the size of the Egyptian shadow economy, the MIMIC model requires to select different indicators that reflect the existence of the shadow economy.

\section{i. Real GDP (index, base year $2005=100$ )}

According to the literature (see below), the relationship between the shadow economy and the official economy is still ambiguous. On one hand, the correlation between the shadow economy and the official economy is positive, while on the other hand it is found to be negative.

Several scholars including Schneider et al. (2010) for 114 countries, Loayza (1996) for 14 Latin American counties, Buehn and Schneider (2008), Schneider and Williams (2013), Buehn and Farzanegan (2012) as well as Dell'Anno et al. (2007) for France, Greece and Spain have 
concluded that there is a negative relationship between the size of the shadow economy and the official one. An increase in the size of the shadow economy leads to a decrease in the official economy because productive resources and factors are absorbed by the shadow economy creating a depressing effect on the growth of the official economy (Schneider and Enste, 2013; Alanon and Go'mez-Antonio, 2005).

However, other scholars argued that there is a positive relationship between the growth of the shadow economy and the official economy. The shadow economy might allow poor people to find ways to produce and sell cheap products as a way of generating income. Hence, it is argued that the shadow economy grows along with the expansion in economic activities because the increased demand in the formal economy spills over into the informal economy leading to greater competitiveness and entrepreneurship. Based on their findings for Asian countries Schneider et al. (2003) concluded that there is a positive relationship between the growth in the shadow economy and the official economy. It is important to note that either way, the relationship between the shadow economy and the official one is not linear, yet the researchers must take care of the level of the development of the country at hand. Schneider (2005) argued that the relationship is negative for the case of developing, while it is positive for the case of developed and transition countries.

In our MIMIC model, the real GDP index (base year 2005=100) is used as an indicator to reflect the existence of the shadow economy in Egypt and to test the relationship between the shadow and the official economy. Since the shadow economy is not directly measured (latent variable), we will set the real GDP index as our reference variable and it is expected to have a negative sign. The value of the variable is fixed to -1 throughout the different model specifications.

Hypothesis 6: The larger the size of the shadow economy, the lower the GDP is, ceteris paribus.

\section{ii. Currency in Circulation}

Irregular and informal transactions are highly expected to be conducted mostly in cash rather than with credit/debit cards, checks or bank transactions in order to avoid detection by auditing controls and government officials. According to the Central Bank of Egypt, money supply increased as a result of an increase in the currency in circulation outside the banking system which rose by $24.2 \%$ in 2013 compared to $15.6 \%$ a year earlier and to $8.7 \%$ in 2009 . Studies by 
various scholars such as Alanon and Go'mez-Antonio (2005), Buehn (2012), Dell'Anno et al. (2007), and Schneider et al. (2010) concluded that there is a significant and positive relationship between size of the shadow economy and currency held by the public. Therefore, in the MIMIC model, money growth is used as an indicator.

Hypothesis 7: The larger the size of the shadow economy, the larger the currency held by the public is, ceteris paribus

\section{iii. Total employment}

The third indicator considered in the MIMIC model is total employment as a share of the total population. The shadow economy absorbs the economic agents from the formal ("official") economy to work informally leading to a reduction in the availability of human resources in the formal economy. Several authors, including Bajada and Schneider (2005), Dell'Anno et al. (2007) and Schneider et al. (2010), included the total labor force participation rate as an indicator of the increased informal activity reflected in the reduction of the labor force rate. However, the general definition of the labor force rate includes the total workforce legible and willing to work; hence employed and unemployed. Thus, we argue that focusing only on total employment gives us a more precise indicator of the shadow economy due to the movement of the economic agents to participate in informal activities. The existence of a relatively large shadow economy in Egypt might lead to the transfer of labour from the formal economy to the shadow economy.

Hypothesis 8: the Targer the shadow economy, the lower total employment is, ceteris paribus.

To summarize: Further causal and indicator variables have been used to estimate the size of the shadow economy around the globe ${ }^{3}$. Those variables include labor force statistics (labor force participation rate, working hours, salaries and wages), government subsidies, social security contributions, or disposable income. Due to a lack of information for the period of our study (1976 to 2013) and for the case of Egypt, such variables were not included in the MIMIC model.

${ }^{3}$ To mention a few, Alanon and Go'mez-Antonio (2005), Dell'Anno et al. (2007), Tedds (2005), Schneider et al. (2010), Buehn and Schneider (2008) and Loayza (1996). 


\subsubsection{Estimation of the MIMIC model}

For the case of Egypt, we use annual data from 1976 to 2013 for

(1) the share of total taxes in GDP,

(2) the polity IV index as a proxy for institutional quality,

(3) agricultural value-added as \% of GDP,

(4) the unemployment rate and

(5) the self-employment rate

as the major causal variables affecting the size of the shadow economy in Egypt. In order to reflect the shadow economy activities, we use

(1) the real GDP index,

(2) currency outside the banking system and

(3) total employment as percentage of the total population

as indicators in our MIMIC model ${ }^{4}$.

Before we conducted the MIMIC estimation, we tested our time series for unit root and cointegration. All of our time-series are non-stationary ${ }^{5}$, and they are co-integrated. Based on the Johannsen Cointegration test, the Trace test indicates 4 cointegrating equations, and also the Max Eigen-value test indicates 1 cointegrating equation. Therefore, we use the time-series in levels in order not to lose the long-run association between the variables and to be able to estimate a longrun MIMIC model. Additionally, there are some assumptions that are violated by our time series. Firstly, based on the Mardia's normality test ${ }^{6}$, the assumption of multi-variate normality is violated. Secondly, the sample size is not large enough $(n=38)$ which strongly influences the chi-

${ }^{4}$ A detailed explanation of the variables is provided in the appendix table (A.4).

${ }^{5}$ The Augmented Dicky Fuller unit root test is provided in the appendix table (A.2)

${ }^{6}$ Three of the multivariate normality tests reject $\mathrm{Ho}$ (multivariate normality) at the 5\% significance level. 
square statistic ${ }^{7}$. In return, we used certain options in STATA 14 module in order to accommodate for these violations. In order to be able to relax the assumption of multi-variate normality, we used the Satorra-Bentler as a special option with the ML estimation to improve the chi-square statistic of goodness of fit in case of non-normal time-series (Satorra and Bentler, 1994). The Satorra-Bentler gives us the same parameters as the default ML estimation. Since the chi-square fit statistic is highly influenced by the sample size, we used the Swain scaling factor in the STATA 14 software to correct for the chi-square statistic in small samples and complex models.

Three specifications of the MIMIC results are presented in table (3.1). Different specifications have been estimated in order to capture the magnitude and the effect of different causal variables on the size of the shadow economy. As being aforementioned, we fix the real GDP index to -1 along all MIMIC specifications. In specification 1, we start with a general specification including all the causal variables. While in specifications 2 and 3, we remove the insignificant variables in order to determine the most important variables that lead to the existence of the shadow economy in Egypt. In the last specification, we focus on the effect of total taxes along with other causal variables including agricultural importance and institutional quality.

\footnotetext{
${ }^{7}$ The chi-square fit statistic will tend to over-reject correctly specified models in case the ratio of the sample size to the number of the parameters is relatively small. Also, multivariate normality is an underlying assumption in the chisquare test (Kline, 2011).
} 
Table 3.1: MIMIC estimation of the size of the shadow economy from 1976 to 2013, yearly data

\begin{tabular}{|c|c|c|c|}
\hline Variables/specifications & $\begin{array}{l}\text { MIMIC1 } \\
5-1-3\end{array}$ & $\begin{array}{l}\text { MIMIC2 } \\
4-1-3\end{array}$ & $\begin{array}{l}\text { MIMIC3 } \\
\text { 3-1-3 }\end{array}$ \\
\hline \multicolumn{4}{|l|}{ Causes } \\
\hline Total_taxes\%GDP & $\begin{array}{l}0.26^{* * * *} \\
(3.99)\end{array}$ & $\begin{array}{l}0.29 * * * \\
(6.38)\end{array}$ & $\begin{array}{l}0.33 * * * \\
(8.54)\end{array}$ \\
\hline Institutional Quality & $\begin{array}{l}-0.48 * * * \\
(-9.01)\end{array}$ & $\begin{array}{l}-0.46 * * * \\
(-9.34)\end{array}$ & $\begin{array}{l}-0.46 * * * \\
(-9.29)\end{array}$ \\
\hline Agriculture valueadded\%GDP & $\begin{array}{l}0.26^{*} \\
(1.75)\end{array}$ & $\begin{array}{l}0.35 * * * \\
(2.67)\end{array}$ & $\begin{array}{l}0.46 * * * \\
(7.48)\end{array}$ \\
\hline Unemployment Rate $\%$ & $\begin{array}{l}-0.10 \\
(-0.70)\end{array}$ & $\begin{array}{l}-0.13 \\
(-0.94)\end{array}$ & \\
\hline Self_employment $\%$ LF & $\begin{array}{l}0.15 \\
(1.07) \\
\end{array}$ & & \\
\hline \multicolumn{4}{|l|}{ Indicators } \\
\hline Real_GDP_index & -1 & -1 & -1 \\
\hline Money_growth\% & $\begin{array}{l}0.66 * * * \\
(13.01)\end{array}$ & $\begin{array}{l}0.65 * * * \\
(11.38)\end{array}$ & $\begin{array}{l}0.65 * * * \\
(11.65)\end{array}$ \\
\hline Total Employment \% population & $\begin{array}{l}-0.86 * * * \\
(-14.28)\end{array}$ & $\begin{array}{l}-0.81 * * * \\
(-14.51)\end{array}$ & $\begin{array}{l}-0.82 * * * \\
(-14.54)\end{array}$ \\
\hline \multicolumn{4}{|l|}{ Statistical tests } \\
\hline Chi2 & 25.98 & 14.63 & 11.55 \\
\hline Pvalue & $(0.0038)$ & $(0.0668)$ & $(0.0728)$ \\
\hline Swain corrected chi2 & 23.44 & 13.37 & 10.69 \\
\hline Pvalue & $(0.0092)$ & $(0.0996)$ & $(0.0983)$ \\
\hline GFI & 0.87 & 0.93 & 0.95 \\
\hline AGFI & 0.94 & 0.96 & 0.97 \\
\hline CFI & 0.911 & 0.961 & 0.967 \\
\hline SRMR & 0.053 & 0.050 & 0.053 \\
\hline $\mathrm{CD}$ & 0.986 & 0.973 & 0.973 \\
\hline Degrees of freedom & 34 & 27 & 21 \\
\hline
\end{tabular}

Absolute z-statistics are reported in parenthesis. ${ }^{*}, * *, * * *$ denote significance at 1,5 and $10 \%$ significance levels. ${ }^{1}$ The statistical test reflecting the quality of models ( 2 and 3 ) are highly acceptable. Goodness of fit index (GFI): values closer to 0.90 reflect a perfect fit. Adjusted GFI: GFI corrected for degrees of freedom. CFI: when the comparative fit index is closer to one, it indicates a good model fit. SRMR: The values less than 0.08 indicate a good model fit. Coefficient of Determination (CD): A perfect fit corresponds to a $C D=1$ (Kline, 2011). Degrees of freedom $=0.5(\mathrm{p}+\mathrm{q})(\mathrm{p}+\mathrm{q}+1)-\mathrm{t}$, where $\mathrm{p}$ :number of causes, $\mathrm{q}=$ number of indicators, $\mathrm{t}=$ number of free parameters. Source: Own calculations

To summarize the MIMIC results, we can conclude that the causal variables behave as expected based on our theoretical considerations except for the unemployment rate and self-employment rate, which proved to be insignificant causes of the Egyptian shadow economy. The main driving factors of the shadow economy in Egypt are the tax burden, institutional quality measured by the 
polity index and the importance of the agricultural sector. Based on the MIMIC specification (MIMIC3), we are able to calculate the size of the shadow economy in Egypt from 1976 to $2013^{8}$ and to visualize the trend and development of the shadow economy as being shown in figure (3.1). The trend of the shadow economy is decreasing from 52\% of official GDP in 1976 to $32 \%$ in 2013. On average, the size of the shadow economy based on the MIMIC model during the period under study is equal to $44 \%$ of GDP and $33 \%$ of GDP based on the CDA.

Figure 3.1: Size and development of the Egyptian shadow economy using the MIMIC model, in \% of GDP

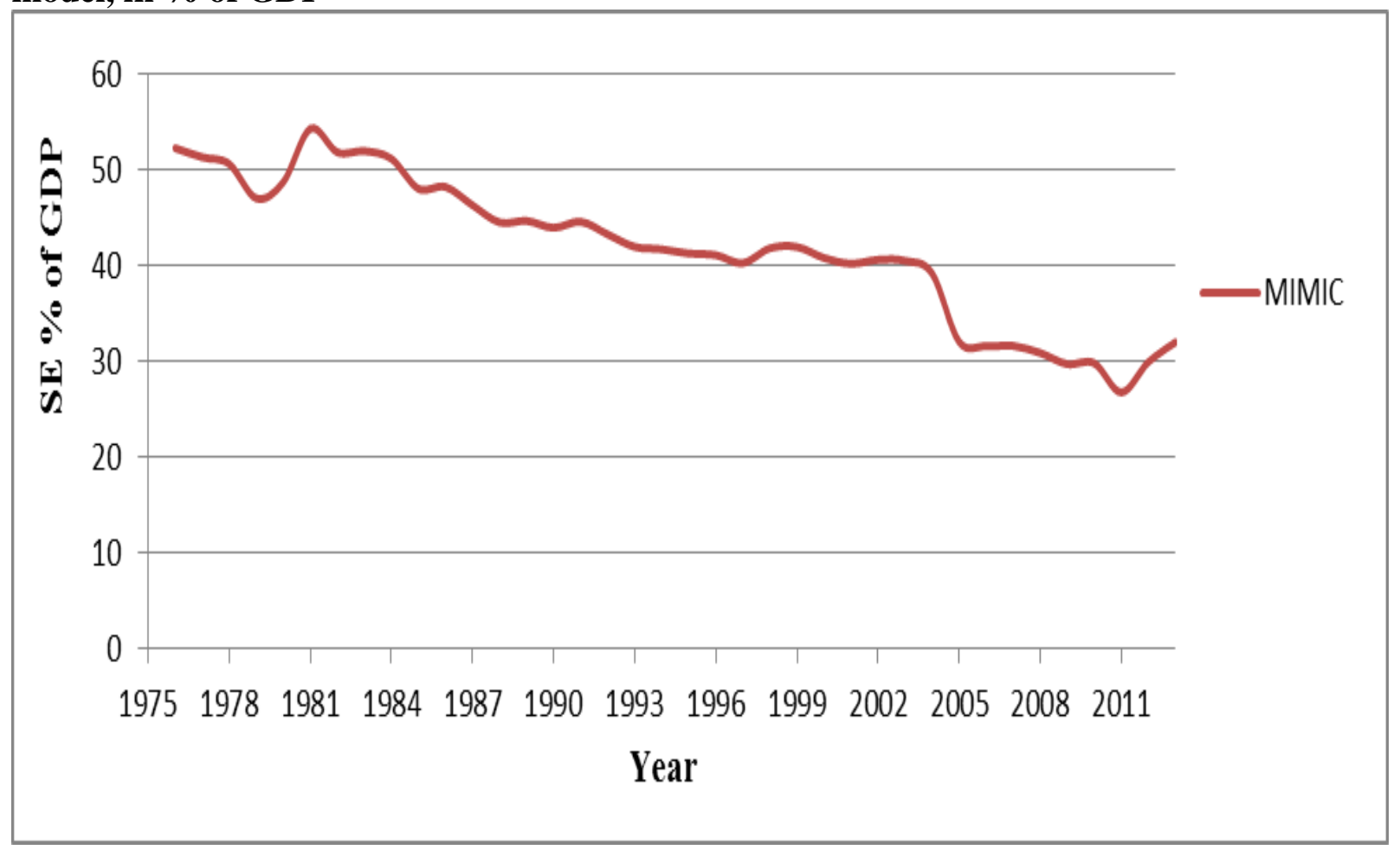

Source: Own Calculations

\footnotetext{
${ }^{8}$ The calibrated values of the size of the shadow economy are provided in the appendix table (A.5). For the starting values of the calibration procedure we used our estimates from the CDA approach for the year 2013.
} 


\subsection{The Currency Demand Approach}

\subsubsection{General remarks}

One of the most widely-used ${ }^{9}$ indirect methods to estimate the size of the shadow economy is the currency demand approach (CDA). The CDA is a monetary approach, mostly referred to as the indicator approach, which measures the discrepancy between the declared/official income and the income covered by the currency demand. The CDA is a macroeconomic approach, too, that uses various variables containing information on the development of the shadow economy over time. The pioneers to apply this method were Cagan (1958) for the case of the United States followed by Gutmann (1977) and Feige (1979). Tanzi (1983) further developed this approach by assuming that the tax burden is one of the core causes of the shadow economy which is then channeled through the excessive demand and use of cash. The main assumption of the CDA is that informal transactions conducted in the shadow economy are mainly in cash in order to avoid any trace of evidence for the official authorities. Any excess demand of cash is then attributed to the variables controlling for the shadow economy. In that sense, an increase in the informal activities in an economy would lead to an excessive use of cash. Therefore, if we can estimate the amount of excessive cash used in the informal activities, then we can estimate the size of the shadow economy by multiplying the amount of cash used in the shadow economy by the income velocity of money.

Formally, there are two steps when estimating the size of the shadow economy by the CDA. The first step is estimating the demand for currency, both for the formal transactions in an economy and also for the informal ones involving the motivation to cover up income. Following the typical Cagan (1958) currency demand function,

$$
C_{0}=a(1+\theta)^{\alpha} Y_{0}^{\beta} \exp (-\gamma i)
$$

where $\mathrm{C}_{0}$ is observed cash and $\Theta$ represents the variable that motivates individuals to conduct informal activities which can be approximated by the tax burden or the intensity of government regulation. This variable is the key variable in the CDA because an increase in $\Theta$ is expected to have a positive impact on currency demand because people are highly motivated to participate in

\footnotetext{
${ }^{9}$ See also Tanzi (1983) being the first, Schneider (1986), Schneider and Enste (2000), Caridi and Passerini (2001), Bajada and Schneider (2005), Alm and Embaye (2013) and Ardizzi et al. (2014).
} 
the shadow economy, hence demanding more cash for their informal transactions. $\mathrm{Y}_{0}$ is the official GDP which represents the level of transactions in an economy. Other measures of the $\mathrm{Y}_{0}$ can be income per Capita or consumption per Capita. $i$ is the interest rate or inflation rate representing the opportunity cost of holding cash. Finally, the A, $\alpha, \beta$, and $\gamma$ are the parameters.

From equation (1), we are able to estimate $\hat{C}$. Then, when we set the incentive variable $(\Theta)$ to the minimum values, we are able to obtain $\dot{C}$. The difference between $\hat{C}$ and $\dot{C}$ gives us the extra currency in an economy, i.e. the illegal money used in the shadow economy to conduct informal transactions. By multiplying the extra currency by the income velocity of currency, we are able to estimate the size of the shadow economy.

\subsubsection{CDA estimation for the case of Egypt}

For the case of Egypt, we use annual data series to cover the period from 1976 to $2013^{10}$. In order to capture the long-run effect of the explanatory variables on currency demand, we model the following specification:

$$
C_{t}=\beta_{0}+\beta_{1} Y / c_{\text {capita }}+\beta_{2}\left(1+\mathrm{TAX}_{\mathrm{t}}\right)+\beta_{3} \mathrm{REG}_{\mathrm{t}}+\beta_{4} \mathrm{SELF}_{\mathrm{t}}+\beta_{5} \mathrm{R}_{\mathrm{t}}+\varepsilon_{\mathrm{t}}
$$

where $C_{t}$ is the natural logarithm of currency in circulation outside the banking system normalized by the GDP deflator, Y/capitat is the natural logarithm of income per capita, TAX is the natural logarithm of total tax revenues normalized by real GDP, $\mathrm{REG}_{\mathrm{t}}$ is approximated by public employment in relation to total labour force as being our regulatory indicator in the model, $\mathrm{SELF}_{\mathrm{t}}$ corresponds to the ratio of self-employment to labour force, and $\mathrm{R}_{\mathrm{t}}$ is the natural logarithm of the nominal deposit interest rate representing the opportunity cost of holding money. $\varepsilon_{\mathrm{t}}$ is the error term.

In addition to the typical independent macro-economic variables (tax burden and regulation intensity measured as the share of public employees in \% of total employment) related to the size of the shadow economy, we added self-employment as a percentage of total labour force as an additional variable to capture the incentives of people participating in the shadow economy and thus increasing the demand for currency ${ }^{11}$. Egypt is characterized as being a labor-abundant country with an increasing population. The new phase of industrialization since the 1952

\footnotetext{
${ }^{10}$ A detailed explanation of the variables is provided in the appendix table (A.3).

${ }^{11}$ Some theoretical considerations about the causal variables of the shadow economy are in section 3.1.1.
} 
revolution focused solely on the capital intensive industries rather than on the labor intensive industries which in return did not create more employment opportunities neither in the public nor in the private sector which then pushed people to seek self-employment opportunities. Not only that, but also the entry regulation in Egypt is burdensome. Based on a study by Djankov et al. (2002), they concluded that a new entrant to the market in Egypt must at least go through 11 procedures at governmental agencies and wait at least 51 business days to obtain a legal status to operate a business. Due to the bureaucratic environment compared to other countries ${ }^{12}$, entrepreneurs are motivated to be self-employed and operate informally. We also included the share of agriculture in GDP as another driving variable for the shadow economy, because in this sector farmers have many possibilities to produce a part of their agricultural goods "black". The larger the share of agricultural production is, the higher is the shadow economy, ceteris paribus. We expect that income per capita, taxes, public employment, self-employment and the share of agricultural production have a positive impact on currency demand while we expect a negative impact of interest rates on currency; encouraging individuals to avoid excessive holdings of currency as the opportunity cost of holding cash increases.

Before starting with the estimation of equation (2), we tested our time series for the presence of unit root and cointegration. Based on the results of the unit root test from the Augmented DickyFuller (ADF) test ${ }^{13}$, the time series are strongly non-stationary at level but when taking the first differences, the time series become stationary. Since the variables are all integrated of the same order I(1), we further test for cointegration based on the Johansen Cointegration test. Before running the Johansen Cointegration test, we determined the optimal lag length estimating a VAR model using the raw data. The optimal lag length is 1 according to LR, FPE, AIC, CS and HQ. With reference to the Johansen Cointegration test, the trace test indicates 3 cointegrating equations at the 5\% and the max-eigenvalue test shows 1 cointegrating equation at the 5\%. We can then conclude that at least 1 cointegrating relationship exists between the variables in the long-run. Given these results, the non-stationarity of the time series and the presence of a long term association between the variables allow us to estimate the currency demand based on our specification and measure the size of the shadow economy by using the vector error correction model (VECM). This type of VEC model is superior to the standard estimation methods because

\footnotetext{
${ }^{12}$ For example, in Tunisia or Israel, one must go through 9 or 5 procedures and wait 41 or 32 days, respectively.

${ }^{13}$ See appendix table (A.1). These tests were run by Eviews 8.
} 
it allows us to capture the short- and the long-run effects. Several authors, including but not limited to Macias and Cazzavillan (2009) and Hernadez (2009), have used the VEC model to estimate the size of shadow economy.

In order to test the robustness of our mode ${ }^{14}$, we replicated model (1) in table 3.2 with real GDP instead of real GDP per capita. Also, in model (3), we added government consumption as percentage of GDP as an additional variable that influences people's incentives and puts more pressure on currency demand. All coefficients have the expected effect and are strongly significant. In model (4), we intend to replicate the MIMIC specification (MIMIC1) in order to include all the macroeconomic variables that influence the shadow economy in our CDA rather than just considering the tax burden. As can be seen from the results, most of the macroeconomic variables affecting the development of the shadow economy behave as expected. However, the interest rate has a positive coefficient which can be interpreted as a positive long-run effect on currency demand which is contradicting our economic theoretical considerations; also model (4) has a weak explanatory power to currency demand. This highlights that the MIMIC model is superior to the CDA to consider different causes and indicators affecting the shadow economy at the same time. It is important to note that an approximation of currency complements such as the usage of debit/credit cards or an approximation of bank transactions were not controlled for in the CDA specification due to data limitations.

\footnotetext{
${ }^{14}$ Another robustness test by varying the sample period is conducted and the results are in appendix table (A.7)
} 
Table 3.2: Estimating the currency demand outside banks from 1976 to 2013, yearly data

\begin{tabular}{|c|c|c|c|c|}
\hline Independent variables & (1) & (2) & (3) & (4) \\
\hline $\mathrm{C}_{\mathrm{t}-1}$ (currency outside banks) & 1.00 & 1.00 & 1.00 & 1.00 \\
\hline $\mathrm{Y}_{\mathrm{t}-1(\text { real income })}$ & & $\begin{array}{c}1.36 * * * \\
(0.06) \\
{[22.91]}\end{array}$ & $\begin{array}{c}1.32 * * * \\
(0.03) \\
{[43.94]}\end{array}$ & \\
\hline $\mathrm{Y}_{\text {capita }}$ t-1 $_{\text {(real income/capita) }}$ & $\begin{array}{c}2.12 * * * \\
(0.09) \\
{[25.03]}\end{array}$ & & & $\begin{array}{c}2.72 * * * \\
(0.06) \\
{[48.66]}\end{array}$ \\
\hline $\mathrm{TAX}_{\mathrm{t}-1}($ total tax burden $)$ & $\begin{array}{c}0.50 * * * \\
(0.09) \\
{[5.76]}\end{array}$ & $\begin{array}{c}0.75 * * * \\
(0.09) \\
{[7.53]}\end{array}$ & $\begin{array}{c}0.42 * * * \\
(0.05) \\
{[7.68]}\end{array}$ & $\begin{array}{c}0.43 * * * \\
(0.04) \\
{[11.50]}\end{array}$ \\
\hline $\mathrm{R}_{\mathrm{t}-1}$ (interest rate) & $\begin{array}{c}-0.23 * * * \\
(0.05) \\
{[4.42]}\end{array}$ & $\begin{array}{c}-0.23 * * * \\
(0.06) \\
{[4.02]}\end{array}$ & $\begin{array}{c}-0.11 * * * \\
(0.04) \\
{[2.80]}\end{array}$ & $\begin{array}{c}0.09 * * * \\
(0.03) \\
{[2.68]}\end{array}$ \\
\hline $\mathrm{REG}_{\mathrm{t}-1}$ (public employmnet) & $\begin{array}{c}0.03 * * * \\
(0.01) \\
{[3.35]}\end{array}$ & $\begin{array}{c}0.04 * * * \\
(0.01) \\
{[3.90]}\end{array}$ & & \\
\hline $\mathrm{SELF}_{\mathrm{t}-1}$ (self employment) & $\begin{array}{c}0.15 * * * \\
(0.01) \\
{[13.37]}\end{array}$ & $\begin{array}{c}0.19 * * * \\
(0.01) \\
{[13.66]}\end{array}$ & $\begin{array}{c}0.11 * * * \\
(0.01) \\
{[11.71]}\end{array}$ & $\begin{array}{c}0.15 * * * \\
(0.004) \\
{[30.68]}\end{array}$ \\
\hline $\begin{array}{l}\mathrm{GOV}_{\mathrm{t}-1} \text { (government } \\
\text { consumption) }\end{array}$ & & & $\begin{array}{c}0.61 * * * \\
(0.08) \\
{[7.30]}\end{array}$ & \\
\hline Agriculture \%GDP & & & & $\begin{array}{c}0.54 * * * \\
(0.07) \\
{[7.60]}\end{array}$ \\
\hline Institutional Quality & & & & $\begin{array}{c}-0.02 * * * \\
(0.007) \\
{[2.35]}\end{array}$ \\
\hline Unemployment rate & & & & $\begin{array}{c}0.003 \\
(0.004) \\
{[0.79]}\end{array}$ \\
\hline Cons & $\begin{array}{c}3.13 * * * \\
(3.52) \\
{[3.52]}\end{array}$ & $\begin{array}{c}-16.17 * * * \\
(1.77) \\
{[9.12]}\end{array}$ & $\begin{array}{c}-14.92 * * * \\
(0.89) \\
{[16.77]}\end{array}$ & $\begin{array}{c}3.52 * * * \\
(0.67) \\
{[5.27]}\end{array}$ \\
\hline Log likelihood & 191.99 & 191.27 & 276.40 & 247.84 \\
\hline Autocorrelation LM test & $\begin{array}{c}24.03 \\
\text { Pvalue } \\
0.9364\end{array}$ & $\begin{array}{c}25.94 \\
\text { Pvalue } \\
0.8922\end{array}$ & $\begin{array}{c}46.20 \\
\text { Pvalue } 0.1187\end{array}$ & $\begin{array}{c}64.90 \\
\text { Pvalue } \\
0.4452\end{array}$ \\
\hline White test & $\begin{array}{l}292.91 \\
\text { Pvalue } \\
0.5070\end{array}$ & $\begin{array}{l}282.27 \\
\text { Pvalue } \\
0.6782\end{array}$ & $\begin{array}{c}298.42 \\
\text { Pvalue } 0.4173\end{array}$ & $\begin{array}{l}- \\
-\end{array}$ \\
\hline
\end{tabular}

All variables are in natural logarithm. The models are estimated with one cointegrating equation. Standard errors are in parentheses() and T-statistics in []. *** significant at the 1\% level. The autocorrelation LM test indicates that there is no residual serial autocorrelation since that the p-value is greater than 5\%. Source: Own calculations

After estimating the VECM and reporting the coefficients as being shown in table (3.2), we are able now to calculate the size of the shadow economy. The first step is to calculate $\hat{C}$, then we set the tax burden, public-employment and self-employment to the minimum level while keeping all else unchanged to estimate $\dot{C}$. The difference between $\hat{C}$ and $C$ gives us the extra currency (EC) 
in the economy. Assuming equal income velocity of money $(V)$ in both the formal and the shadow economies (Tanzi, 1983), the size of the shadow economy is estimated by multiplying the EC with the velocity ${ }^{15}$.

$$
\mathrm{Y}_{\text {informal }}=\mathrm{EC}^{*} V
$$

Based on equation (3), we can then infer the size of the shadow economy in Egypt as a percentage of official GDP and approximate the evolution of the size of the shadow economy in Egypt from 1976 to 2013.

It is important to note that the key assumption that the velocity is equal in both economies only holds when the coefficient of $\mathrm{Y}$ is equal to one $(\beta=1)$. However, as being reported in table (3.2), the coefficient of $Y$ in our specification is different from one $(\beta=2.12)$. As a result, we need to correct our results following the proposed method by Ahumada et al. (2007).

$$
\frac{Y_{\text {informal }}}{Y_{\text {formal }}}=\left(\frac{C_{\text {informal }}}{C_{\text {formal }}}\right)^{\frac{1}{\beta}}=\left(\frac{\hat{Y}_{\text {informal }}}{\hat{Y}_{\text {formal }}}\right)^{\frac{1}{\beta}}
$$

where $\mathrm{Y}$ and $\mathrm{C}$ are GDP and money, respectively, while $\beta$ is the income elasticity. Based on this method, the estimates of the size of the shadow economy are corrected when $\beta$ is not equal to 1 . This correction method has been applied in recent studies including Macias and Cazzavillan (2009), Hernandez (2009) and Pickhardt and Sarda (2010, 2011). Based on this modified CDA, the size of the shadow economy in Egypt in \% of GDP based on model (1) is shown in the following figure (3.2).

As can be seen from the figure, the shadow economy in Egypt constituted a major portion of official GDP until the mid-1980s with a decreasing tendency. However, starting in the early 90s, it stabilizes on average between $20 \%-30 \%$ of GDP. As being expected, in model (1) which corresponds to our specified model in equation (2), the coefficients for income per capita, total tax burden, intensity of regulation and self-employment have a positive and strongly significant long-run effect on currency demand. Also, as expected, interest rates have a significant reducing effect on currency demand.

\footnotetext{
15 The income velocity of money is extracted from the economic bulletin published by the Central Bank of Egypt.
} 
Figure 3.2: Size and development of the Egyptian shadow economy in \% of GDP using CDA

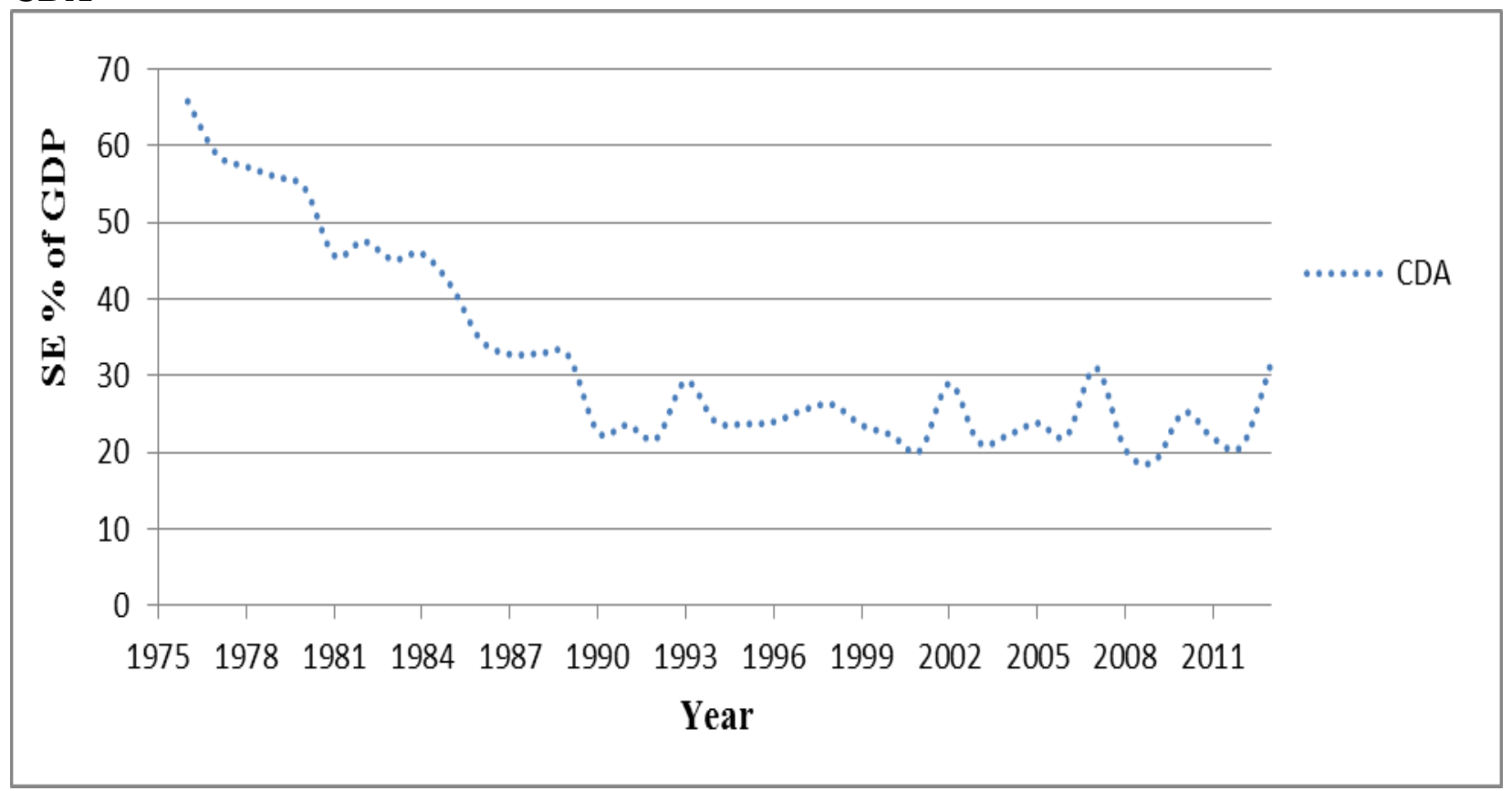

Source: Own calculations

Although the CDA is one of the mostly used methods to estimate the size of the shadow economy, it has been subject to major criticisms:

(1) The main assumption of the method is that all transactions are conducted in cash to avoid traceability. However, not all informal transactions are made in cash.

(2) The method ignores the possibility of a barter shadow economy leading to the undervaluation of the total size of the shadow economy. Based on their survey, Isachsen and Strom (1985) concluded that approximately $80 \%$ of the informal activities in Norway were conducted in cash.

(3) The assumption of no shadow economy in a base year is highly criticized.

(4) The assumption of the equal velocity of money in both the formal and the shadow economies is among the highlighted limitations of the CDA.

(5) Another important criticism is that most of the CDA models consider only one variable, which is the tax burden (Schneider, 1986). Moreover, the CDA considers only one indicator, hence currency, to reflect the shadow economic activities. 
Quite often the MIMIC model is considered superior to the CDA because the MIMIC model allows the researcher to consider several causes and indicators at the same time to model the evolution of the shadow economy over time.

\section{Analysis and Implications}

As can be seen from the trend of the shadow economy in $\mathrm{Egypt}^{16}$ in figure (4.1), the largest size of the shadow economy based on the CDA and MIMIC model during the period of my study was in year 1976 reaching $58 \%$ and 66\% of GDP, respectively. This large value can be explained by the major recessions of the economy after the 1973-war with Israel. During the 70s (from 1973 to 1978), the Egyptian economy was still suffering from the war time. The Egyptian government had focused to fund military spending by purchasing weapons and rebuilding and improving the military infrastructure that was destroyed in the defeat of the 1967 war and also many Egyptians had left their employment positions in order to join the military and fight in the war. The Egyptian economy was burdened not only because of the shift of funding to the military but also due to the major economic losses during the war time that included losses in tourism revenues, losses in capital resources and Suez Canal revenues. Therefore, the government needed to undertake necessary policies to restore the military infrastructure and to find ways to fund its military spending. These policies included raising the direct and indirect tax revenues, with direct taxes increasing by $47 \%$ and indirect taxes increasing by $22 \%$ from 1970 until the early 1980 s. Not only that, but also the central bank printed more money to raise funds to cover up military spending. As a result of these policies, the size of the shadow economy in Egypt during this war time and after the war reached its highest share of GDP of the observed period; reaching on average more than $50 \%$ of GDP.

\footnotetext{
${ }^{16}$ Both the CDA and the MIMIC model show a downward trend of the development of the Egyptian shadow economy. The correlation coefficient between the two series is highly significant at $0.7292(0.0000)$.
} 
Figure 4.1: A comparison of the size and development of the Egyptian shadow economy using the CDA and MIMIC model, 1976 to 2013

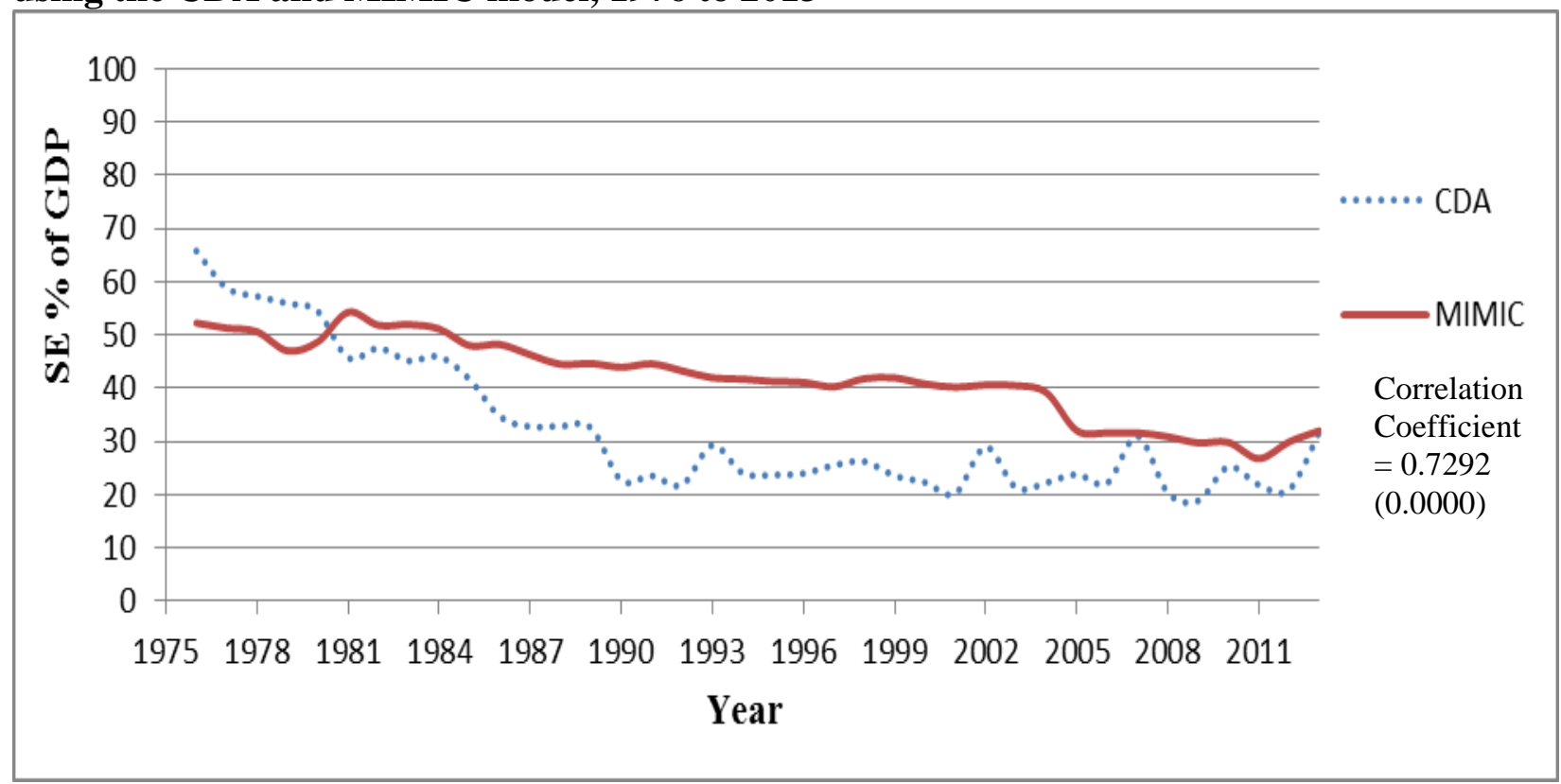

Source: Own calculations

During the 80 s and 90 s, the size of the shadow economy was fluctuating with a decreasing trend, yet this period evidenced a large share of the shadow economy until the new millennium. However, there was a decrease starting in 2005 and a major drop in the size of the shadow economy starting in the year 2007 in which the size of the shadow economy decreased to $31 \%$ of GDP. This major drop is due to the major economic reforms that the Egyptian government executed in 2004/2005. These major economic reforms focused on improving the tax system in Egypt which resulted in initiating a new tax law. The goal of this tax reform was to simplify the tax law and to induce the same and equal tax burden for all businesses and economic units without any exceptions, tax holidays or special considerations in order to create a fair tax treatment for everyone as well as to encourage tax compliance. There was a media campaign by the end of 2004 to inform the public about the major changes and improvements and to create an environment of trust between the tax authority and the tax payer. In 2005, Law 91/2005 was approved by the Egyptian parliament which put into action a reduction of tax rates, a clarification and simplification of the tax law and, most importantly, an improvement of the tax administration to be more transparent. One of the major benefits of this reform was the decrease in tax evasion as the government and the tax authority announced under the new law that there shall be a 'forgiven act' for whoever was evading paying taxes, on the condition that they register themselves in the tax authority within a certain period of time which in return resulted in the 
formalization of many informal activities. Thus, the reduction in the tax rates along with the major improvements of the tax authority discouraged the public to evade taxes and engage in the shadow economy which can be seen in the reduction of the size of the shadow economy during this period and in the major increase in tax filings by $50 \%$.

With reference to the 2011 revolution, we can conclude mixed results. At the year of the revolution, the size of the shadow economy was at its smallest (22\% and 27\% based on the CDA and MIMIC model, respectively) as the individuals were revolting for better economic performances and development. However, the years following the revolution suffered from the lowest official economic growth (1.7\% growth in 2011 followed by a 2\% growth in 2012) and many people have lost their jobs due to the contraction in the economy and due to political instability as many, especially international organizations, have closed and moved their operations elsewhere. Given increasing unemployment during those years (from 9\% in 2010 to 13.2\% in 2013) and a contracting economy, many people were attracted to join the shadow economy as a safe harbor to earn income and to buy cheaper goods. As a result, the shadow economic activity rose in Egypt in the aftermath of the revolution reaching $32 \%$ of GDP.

The total tax burden, as expected, is a significant and a determining factor affecting the size of the shadow economy in all specifications. Tax revenues are a major source of finance to the government to the extent that the weight of tax revenues is on average more than $60 \%$ of total revenues. Since the tax burden plays a significant role in influencing participation in the shadow economy, our recommendation is that policy makers should implement major tax reforms and introduce educational campaigns in order to improve tax compliance and increase tax morale. Egypt has the highest tax rate bracket on income (32-40\%) compared to its neighboring MENA countries like Lebanon or Jordan (charging 15\%). Not only that, Egypt suffers from a lack of trust between the tax payers and the tax authorities. As a result a new major tax law reform was executed in 2005 to reduce tax rates and to clarify tax rules in order to increase tax payments and compliance. The outcome of this reform was an increase in tax filings by $50 \%$ which is also reflected in the downward trend in the size of the shadow economy after the reform was being introduced.

Yet, it is important to highlight that the implementation of tax reforms should be accompanied by improvements in the quality of institutions. Thus, the dynamics of the tax burden with the quality 
of institutions should not be ignored by the officials. As concluded from the MIMIC findings, the quality of institutions significantly affects the peoples' perceptions and motivation to engage in informal activities. Therefore, we urge the policy makers to increase the quality of institutions by creating a democratic transparent environment and by reducing bureaucracy and over-regulation.

With reference to the CDA outcomes, self-employment and government regulation measured by public employment, in addition to the tax burden, significantly affect the shadow economy which is then channeled by an excess currency demand evidenced by the positive and significant coefficients of these variables in our specifications. Unlike in the CDA specifications, the selfemployment quota in Egypt based on the MIMIC specification (1) positively affects the motivation of economic agents to participate in the shadow economy, yet it does not necessary lead to an increase in the size of the shadow economy in Egypt reflected in the insignificance of the variable.

For the case of Egypt, it is the first time to test for the quality of democratic institutions. Based on the MIMIC specification (3), the relative impact of democracy is $46 \%$. Democracy has become an important issue for Egypt since the outbreak of the revolution in 2011, as one of the main goals of the revolution is to create a democratic environment. Not only that, but also democracy plays an important role affecting the citizens' motivation to participate in the shadow economy. Firstly, in a democracy, there is an increased public participation. Democracy grants the public the right to be actively involved in the policy making process through their voting rights. For instance, if tax payers can vote on how taxes will be spent, then they will be less motivated to evade taxes by engaging in the shadow economy. Democracy ensures that the public's opinions and priorities are heard and most importantly accounted for in the public policies. Therefore, the implemented policies are efficient, reflect public preferences and lead to better public spending on goods and services. This democratic public involvement enhances trust between the government and the public and increases the publics' civic virtue and tax morality which in return reduces shadow economy participation. Secondly, democracy grants the public the 'voice option' to be able to monitor and hold the government liable and accountable. This in return improves the legitimacy of the government through controlling the government's policies via referenda or threat of ballot. Also, the voice option reduces the policy-makers' conflict of interest and rentseeking activities which in return improves the public's perception of the government (Solomon and Schrestha, 2014; Teobaldelli and Schneider, 2013; Torgler and Schneider, 2007). As being 
shown in the MIMIC outcomes, we can conclude that democracy lowers the incentives of the individuals to participate in the shadow economy. Therefore, the government needs to improve its quality of institutions and to create a democratic and trustworthy environment between the government officials and the public in order to discourage people to engage in informal activities.

In order to be able to determine the major factors that affect the development and size of the shadow economy in Egypt, the importance of the agricultural sector as measured by agricultural value-added as \% of GDP should not be neglected. As per the findings, we can conclude that a large and dominating agricultural sector significantly affects the shadow economy in Egypt. The country's economic structure highly depends on the agricultural sector as a source of growth and support for other economic sectors. Figures show that total agricultural production increased by $20 \%$ during the last decades and employment in agriculture is larger compared to employment in the industrial sector. Due to the importance of the agricultural sector, the structural adjustment program in 1987 and the major policy reform in the 1990s focused on increasing agricultural production and income. Given the lack of proper education for Egypt's growing population and the concentration of households in rural areas, individuals highly depend on farming and agriculture-related activities as a source of income. Therefore, we can conclude that given the importance of the agricultural sector in Egypt and given its significant effect on the shadow economy, the government needs to efficiently formalize the agricultural sector by providing incentives for the public engaging in agricultural activities to discourage them from being informal.

It is interesting to note that the unemployment rate has a negative effect on the size and development of the Egyptian shadow economy which is contrary to what we hypothesized. Such a behavior can be explained by the argument that job opportunities are also unavailable in the shadow economy in countries in which unemployment is steadily high. With reference to Egypt, the unemployment rate has been increasing steadily throughout the years from $1.6 \%$ in 1973 to $9 \%$ in 2000 and to $13 \%$ in 2013 . This shows that the overall economy has been contracting and in a recession, as being reflected by increasing unemployment, which makes it harder to find employment in both the formal and the informal economy. Also, this effect is reinforced by the study of Schneider et al. (2010) in which they concluded that high unemployment rates for the case of developing countries including Egypt do not necessarily lead to a larger size of the shadow economy. 
A final policy implication is based on the finding that the coefficient of the official economy and the shadow economy is negative. This draws our attention to the conclusion that when the official economy grows, then people are discouraged to undertake informal activities resulting in the efficiency of the market economy and in the formalization of the shadow economy.

\section{Conclusion}

It is important to note that there is no consensus in the literature on the best method to estimate the size of the shadow economy, therefore we apply two of the most widely used approaches to approximately estimate the size as well as the development of the shadow economy in Egypt by using both the CDA and MIMIC model to capture the dynamics of the complex nature of the shadow economy. Both methods came to the same conclusion that the shadow economy accounts for a major proportion of the official economy, yet it has a decreasing trend over time. Our results show that the shadow economy in Egypt accounted for more than 50\% of GDP by the start of our study (1976) and decreased to 32\% of GDP in 2013. As can be seen from table (5.1), all of our hypotheses have been confirmed by both the MIMIC and CDA, except for the impact of unemployment on the shadow economy in Egypt. It can be concluded that a high level of unemployment in Egypt does not necessarily lead to a larger size of the shadow economy.

Table 5.1: Empirical confirmation of our hypotheses

\begin{tabular}{|l|c|c|}
\hline Variables (Hypothesized sign) & Method(s) & Result \\
\hline (1) Total tax burden (+) & MIMIC & Both Confirmed \\
\hline $\begin{array}{l}\text { (2) Quality of democratic } \\
\text { institutions (-) }\end{array}$ & CDA & Both Confirmed \\
\hline $\begin{array}{l}\text { (3) Size of agricultural sector } \\
(+)\end{array}$ & CDA & Both Confirmed \\
\hline $\begin{array}{l}\text { (4) Self-employment (+) } \\
\text { (5) Regulation (+) }\end{array}$ & CDA & Both Confirmed \\
\hline (6) Unemployment (+) & CDA & Confirmed \\
\hline
\end{tabular}




\begin{tabular}{|l|c|c|}
\hline (7) Official GDP (-) & MIMIC & Confirmed \\
\hline (8) Currency (+) & MIMIC & Confirmed \\
\hline (9) Total employment & MIMIC & Confirmed \\
\hline
\end{tabular}

Source: Authors

Since each method has its own strengths and weaknesses and since the shadow economy is by nature untraceable, the estimates of the shadow economy should be interpreted as an approximation of the size of the shadow economy, rather than being exact measures. We gain information from the methods on the most important factors that influence the proliferation of the shadow economy and about the trend and development of the shadow economy in Egypt.

Our study provides an example of the evolution of the shadow economy in a developing country focusing on the case of Egypt. Our first conclusion is that the shadow economy has a decreasing trend, yet it accounts for a large portion of GDP. Secondly, the stagnation of the shadow economy at a high proportion of GDP during the last decade reflects the failure of public policies to tackle the shadow economy and to drive economic growth. Thirdly, Egypt is a labor-abundant country with an increasing population of 88 million inhabitants and a 610 billion Egyptian Pounds worth of GDP in 2013. The forth conclusion is that the shadow economy accounts for a huge weight on the official economy leading to some negative externalities and hence hindering the development of the country. The fifth conclusion is that for the case of a developing country like Egypt, the shadow economy is not necessarily seen as a foe to the formal economy. The shadow economy creates stimulating effects because the income earned informally is later spent in the formal economy. Also, the shadow economy adds to the dynamics of the formal economy by creating markets that otherwise would not be possible such as small scale production and services. Additionally, the shadow economy can act as an employer of last resort where people find job opportunities not otherwise possible, for example during recessions and crises. The shadow economy in Egypt acted like a sponge absorbing all the people that were laid off as a result of the economic and political instability that happened in Egypt after the 2011 revolution.

The big challenge for policy makers is to know to what extent they should tackle the shadow economy. It is interesting to note that to some extent the shadow economy is "good" for a developing economy and that the shadow economy provides stability. The Arab Spring movement that started in 2011 was triggered by an informal street vendor who set himself on fire 
because the police officers detained him from performing his informal activities. From our results, the policy makers can identify the major factors that influence peoples' incentives to participate in the shadow economy in order to be able to correctly channel their policies and reforms and formalize the shadow economy. Most importantly, policy makers need to focus on the quality of institutions by creating democratic and transparent institutions with lower regulatory burden, corruption and bureaucracy in order to be able to restore the trust and confidence of the economic agents in the overall system of the country and to be able to have effective strategies to reduce the Egyptian shadow economy.

We finally recommend that a future line of research should analyze the Egyptian shadow economy from a micro-level approach such as conducting direct surveys in order to provide a deeper understanding of the dynamics of the shadow economy, the profile of the participants and their motivations.

\section{References}

Ahumada, H., Alvaredo, F., \& Canavese, A. (2007). The monetary method and the size of the shadow economy: A critical assessment. Review of Income and Wealth, 53(2), 363-371.

Alañón, A., \& Gómez-Antonio, M. (2005). Estimating the size of the shadow economy in Spain: a structural model with latent variables. Applied Economics, 37(9), 1011-1025.

Alm, J., \& Embaye, A. (2013). Using dynamic panel methods to estimate shadow economies around the world, 1984-2006. Public Finance Review, 41(5), 510-543.

Angel-urdinola, D. F., Urdinola, D. F. A., \& Tanabe, K. (2012). Micro-Determinants of Informal Employment in The Middle East and North Africa Region, Social Protection and Labour, The World Bank, SP Discussion paper (1201), 48.

Ardizzi, G., Petraglia, C., Piacenza, M., \& Turati, G. (2014). Measuring the Underground Economy with the Currency Demand Approach: A Reinterpretation of the Methodology, With an Application to Italy. Review of Income and Wealth, (4), 747-772.

Bajada, C., \& Schneider, F. (2005). The shadow economies of the Asia-Pacific. Pacific Economic Review, 10(3), 379-401.

Buehn, A. (2012). The Shadow Economy in German Regions: An Empirical Assessment. German Economic Review, 13(3), 275-290.

Buehn, A., Farzanegan, M. R. (2013). Impact of Education on the Shadow economy: Institutions matter. Economic Bulletin, 33(3), 2052-2063. 
Buehn, A., \& Schneider, F. (2008). MIMIC Models , Cointegration and Error Correction : An Application to the French Shadow Economy. Forschungsinstitut Zur Zukunft Der Arbeit Institute for the Study of Labor, (3306), 4-30.

Cagan, P. (1958). The Demand for Currency Relative to the Total Money Supply. Journal of Political Economy, 66, 1-33

Caridi, P. \& Passerini, P. (2001). The Underground Economy, The Demand for Currency Approach and The Analysis of Discrepancies: Some Recent European Experience. Review of Income and Wealth, 47(2), 239-250.

Chaudhuri, K., Schneider, F., \& Chattopadhyay, S. (2006). The size and development of the shadow economy: An empirical investigation from states of India. Journal of Development Economics, 80(2), 428-443.

Chen, M. A. (2007). Rethinking the Informal Economy Linkages with the Formal Economy and the Formal Regulatory Environment. DESA Working Paper, 1(46), 1-30.

Dell'Anno, R., Gómez-Antonio, M., \& Pardo, A. (2007). The shadow economy in three Mediterranean countries: France, Spain and Greece. A MIMIC approach. Empirical Economics, $33,51-84$.

Dell'Anno, R., \& Schneider, F. (2009). A Complex Approach to Estimate The Shadow Economy: The Structural Equation Modelling. In Coping with Complexity of Economics, Springer,111-130.

Djankov, S., La Porta, R., Lopez-de-Silanes, F., \& Shleifer, A. (2002). The regulation of entry. The Quarterly Journal of Economics, CXVII(February), 437-452.

Farzanegan, M. R. (2009). Illegal trade in the Iranian economy: Evidence from a structural model. European Journal of Political Economy, 25(4), 489-507.

Feige, E. (1979). How Big is the Irregular Economy?. Challenge,22(1)

Frey, B. S., \& Weck-Hanneman, H. (1984). The hidden economy as an "unobserved" variable. European Economic Review, 26(1-2), 33-53.

Gërxhani, K., \& Van De Werfhorst, H. G. (2013). The effect of education on informal sector participation in a post-communist country. European Sociological Review, 29(3), 464-476.

Gao, S., Mokhtarian, P. L., \& Johnston, R. a. (2009). Nonnormality of Data in Structural Equation Models. Transportation Research Record: Journal of the Transportation Research Board, 2082(-1), 116-124.

Gutmann, P. M. (1977). The Subterranean Economy. Financial Analysts Journal, 33(6), 25$26+34$. 
Hernandez, M. A. (2009). Estimating the size of the hidden economy in Peru: A currency demand approach. Revista de Ciencias Empresariales Y Economia, (8), 85-104.

Hu, L., \& Bentler, P. M. (1998). Fit indices in covariance structure modeling: Sensitivity to underparameterized model misspecification. Psychological Methods, 3(4), 424-453.

Hu, L. \& Bentler, P. M. (1999). Cutoff criteria for fit indexes in covariance structure analysis: Conventional criteria versus new alternatives. Structural Equation Modeling, 6(1), 1-55

Iacobucci, D. (2010). Structural equations modeling: Fit Indices, sample size, and advanced topics. Journal of Consumer Psychology, 20(1), 90-98.

Isachsen, A. J., \& Strøm, S. (1985). The size and growth of the hidden economy In Norway. $R e$ view of Income and Wealth, 31(1), 21-38.

Joreskog, K. G., \& Goldberger, A. S. (1975). Estimation of a Model with Multiple Indicators and Multiple Causes of a Single Latent Variable. Journal of the American Statistical Association, 70(351), 631-639.

Johnson, Simon Kauffman, Daniel Zoido-Lobaton, P. (1997). Regulatory Discretion and the Unofficiai Economy. American Economic Review Papers and Proceedings, 88(2), 387-393.

Kline, R. B. (2011). Principles and Practice of Structural Equation Modelling. Third Edition. The Guilford Press

Loayza, N. V. (1996). The economics of the informal Sector : a simple model and some empirical evidence from Latin America, , 45, 129-162.

Macias, J. B., \& Cazzavillan, G. (2009). The dynamics of parallel economies. Measuring the informal sector in Mexico. Research in Economics, 63(3), 189-199.

Macias, J.B., \& Cazzavillan, G. (2010). Modeling the informal economy in Mexico: a structural equation approach. Journal of Developing Areas, 44(1), 345-365

Nagarajan, K. V. (2013). Egypt's Political Economy and the Downfall of the Mubarak Regime. International Journal of Humanities and Social Science, 3(10), 22-39.

Petersen, H.G., Thießen, U., \& Wohlleben, P. (2010). Shadow Economy, Tax Evasion, and Transfer Fraud - Definition, Measurement, and Data Problems. International Economic Journal, 24(4), 421-441.

Pickhardt, M., \& Sarda, J. (2010). The size of the underground economy in Germany: a correction of the record and new evidence from the modified-cash-deposit-ratio approach. European Journal of Law and Economics, 32(1), 143-163. 
Pickhardt, M., \& Sarda, J. (2011). The size of the underground economy in Germany: a correction of the record and new evidence from the modified-cash-deposit-ratio approach. European Journal of Law and Economics, 32(1), 143-163.

Razmi, M. J., Falahi, M. A., \& Montazeri, S. (2013). Institutional Quality and Underground Economy of 51 OIC Member Countries. Universal Journal of Management and Social Sciences, 3(2), 1-14.

Satorra, A., \& Bentler, P. M. (1994). Corrections to test statistics and standard errors in covariance structure analysis. Latent Variable Analysis: Applications to Developmental Research

Schneider, F. (1986). Estimating the size of the Danish shadow economy using the currency demand approach: An attempt. The Scandinavian Journal of Economics, 88(4), 643-668.

Schneider, F. (2000). Dimensions of the Shadow Economy. Independent Review, 5(1), 81-91.

Schneider, F. (2005). Shadow economies around the world: What do we really know? European Journal of Political Economy, 21(3), 598-642.

Schneider, F., Buehn, A., \& Montenegro, C. E. (2010). New Estimates for the Shadow Economies all over the World. International Economic Journal, 24(4), 443-461.

Schneider, F., \& Enste, D. H. (2013). The Shadow Economy, An International Survey: $2^{\text {nd }}$ Edition. Cambridge University Press.

Schneider, F., \& Enste, D. H. (2000). Shadow Economies: Size, Causes, and Consequences. Journal of Economic Literature, XXXVIII, 77-114.

Schneider, F. (2010). The influence of public institutions on the shadow economy: An empirical investigation for OECD countries. Review of Law and Economics, 6(3), 113-140.

Schneider, F., \& Williams, C. C. (2013). The Shadow Economy. The Institute of Economic Affairs.

Schneider, F., Chaudhuri, K., \& Chatterjee, S. (2003). The Size and Development of the Indian Shadow Economy and a Comparison with other 18 Asian Countries: An Empirical Investigation (Vol. 43).

Schumacker, R. E., \& Lomax, R. G. (2010). A Beginner's Guide to Structural Equation Modelling. Third Edition. Routledge, UK.

Singh, R. (2009). Does my structural model represent the real phenomenon?: a review of the appropriate use of Structural Equation Modelling (SEM) model fit indices. The Marketing Review, 9(3), 199-212.

Smith, P. (1994). Assessing the size of the underground economy: the statistics canada perspective. Canadian Economic Observer, 28, 13-604. 
Solomon, O. H., \& Shrestha, S. (2014). Does the Informal Sector Thrive Under Democracy or Autocracy?: The Case of Nepal. The Journal of Developing Areas, 48(3), 245-267.

Tanzi, V. (1983). The underground economy in the United States: annual estimates, 1930-80. Staff Papers - International Monetary Fund, 30(2), 283-305.

Tanzi, V. (1999). Uses and abuses of estimates of the underground economy. The Economic Journal, 109(456), 338-347.

Tafenau, E., Herwartz, H., \& Schneider, F. (2010). Regional Estimates of the Shadow Economy in Europe. International Economic Journal, 24(4), 629-636.

Tedds, Lindsay (2005). The Underground Economy in Canada. Published in: in Size, Causes and Consequences of the Underground Economy, Chris Bajada and Friedrich Schneider eds. , Ashgate Publishing, UK (2005)

Teobaldelli, D., \& Schneider, F. (2013). The influence of direct democracy on the shadow economy. Public Choice, 157(3-4), 543-567.

Torgler, B., \& Schneider, F. (2007). Shadow economy, tax morale, governance and institutional quality: a panel analysis, (2563), 55. Retrieved from http://papers.ssrn.com/sol3/papers.cfm?abstract_id=960012

Vuletin, G. J. (2008). Measuring the Informal Economy in Latin America and the Caribbean. IMF Working Papers, 08(102), 1.

Wedderburn, C., Chiang, E. P., \& Rhodd, R. (n.d.). The informal economy in Jamaica: Is it feasible to tax this sector? Journal of International Business and Cultural Studies, 1-13.

Williams, C. C. (2006). Evaluating the magnitude of the shadow economy: a direct survey approach. Journal of Economic Studies, 33(5), 369-385.

Zellner, A. (1970). Estimation of Regression Relationships Containing Unobservable Independent Variables. International Economic Review, 11(3), 441-454.

\section{Appendices}

\section{A1. Measuring the shadow economy}

\section{A1.1 General Remarks}

There are various ways to estimate the size of the shadow economy for a certain country. These methods include the direct method, indirect method and the model approach. The direct method which is also called the microeconomic approach helps to gather first-hand data about the shadow economy by having contacts with or observations of individuals or firms. This approach is used 
extensively by various scholars such as Isachsen and Strom (1985), Gërxhani \& Van De Werfhorst (2013) or Williams (2006) to understand intensely the nature of the shadow economy. Examples of the direct method are well-designed and sampled surveys as well as auditing of tax returns and other compliance methods. The limitation of this direct method is the cooperation and response of the representatives questioned in the sample. In the case of carrying out direct questionnaires, there is high chance that the respondents are reluctant to answer questions related to informal work and income. Although, the direct method provides detailed information about the structure and composition of the shadow economy in a certain country but their major disadvantage is that they do not reflect all the shadow economic activities and that they result in only point-time estimates of the size of the shadow economy. The direct methods are unable to estimate the development and growth of the shadow economy over a long period of time and are lower-bound estimates for the true size of the shadow economy (Schneider and Enste, 2013; Dell'Anno et al., 2007).

The second approach to measure the size of the shadow economy is indirect; mostly referred to as the 'indicator' approach. Indirect methods are macroeconomic approaches capturing the traces that the shadow economy leaves in the official statistics as information on the size of the shadow economy. The major criticism is that they only consider one aspect that is supposed to capture all the effects and the complexity of the shadow economy. The four main indirect methods ${ }^{17}$ are

1. The discrepancy between national expenditure and income statistics.

2. The discrepancy between official and actual labor force.

3. The monetary methods: CDA.

4. The physical input (electrical energy consumption) method.

The last method to estimate the shadow economy is called the statistical model or Multiple Indicator Multiple Cause (MIMIC) ${ }^{18}$ which will be discussed in detail in the following sections. The MIMIC model is a particular type of structural equation modeling which is commonly applied in social science research such as in psychology or sociology. The model is based on the statistical theory of 'unobserved' variables developed by Zellner (1970) and Joreskog and Goldberger (1975). The pioneers to apply the MIMIC model in their estimation of the shadow economy as a latent variable were Frey and Week-Hannemann (1984) to measure the size of the

\footnotetext{
${ }^{17}$ For a detailed description, see Schneider and Enste (2013)

${ }^{18}$ Dell'Anno and Schneider (2009) provide a detailed discussion of the SEM, MIMIC, advantages and disadvantages of the MIMIC model
} 
hidden economy for OECD countries from 1960 to 1973. Following them, various scholars including but not limited to Tafenau et al. (2010); Tedds (2005); Schneider et al. (2010); Dell'Anno (2006); Buehn and Farzanegan (2012), Farzanegan (2009); Chaudhuri et al. (2006) have also applied this model approach in the estimation of the informal economy.

\section{A1.2 MIMIC Model Specification}

The MIMIC model is superior to the other methods because various observable and measurable causes and indicators are considered at the same time regarding this complex and unrecorded nature of the shadow economy. The MIMIC model is a theory-based approach ${ }^{19}$ to confirm the influence of a set of exogenous causal variable on the latent variable (shadow economy), and also the effect of the shadow economy on macroeconomic variables (Farzanegan, 2009). Therefore, the MIMIC model is rather a confirmatory than explanatory method (Schneider et al., 2010). The hypothesized path of the relationships between the observed variables and the latent shadow economy based on our theoretical considerations is being visualized in figure (A.1) in the appendix.

The MIMIC model estimates the relationship between observable variables and a latent variable (shadow economy) by reducing the distance between the sample covariance matrix $S$ and the covariance matrix $\sum(\theta)$ predicted by the model.

Formally, the MIMIC model has two parts: the structural model and the measurement model. The structure model is illustrated as follows:

$\eta=\gamma_{1} \chi_{1}+\gamma_{2} \chi_{2}+\ldots+\gamma_{q} \chi_{q}+\varsigma$

where $\chi_{i}$ is a vector of causal variables, $\gamma_{i}$ are scalars, $\eta$ is the latent variable (shadow economy) and $\varsigma$ is a structural disturbance term. The structural model shows that the latent variable $\eta$ is linearly determined by a set of exogenous causal variables. However, these variables only explain partially the latent variable $\eta$, the error term $\varsigma$ represents the unexplained part.

The measurement model which links the shadow economy with the set of selected indicators is specified by:

\footnotetext{
${ }^{19}$ For the theoretical explanation of the variable, refer back to sections (2.2.2 and 2.2.3)
} 
$\gamma_{1}=\lambda_{1} \eta+\varepsilon_{1}$

$\gamma_{2}=\lambda_{2} \eta+\varepsilon_{2}$

$\gamma_{p}=\lambda_{p} \eta+\varepsilon_{p}$

where $\gamma_{i}$ are the indicator variables, $\lambda_{i}$ are the loading factors to represent the magnitude of expected change for a unit change in the latent variable $\eta$. The $\varepsilon_{i}$ is the measurement error term. Both the structural disturbance term $\varsigma$ and the measurement error term $\varepsilon_{i}$ are independent and are assumed to follow a standard normal distribution with a mean of zero and constant variance (Dell'Anno and Schneider, 2009).

Equations (1) and (2) can be summarized as follows:

$\eta=\gamma^{\prime} x+\varsigma$

$y=\lambda \eta+\varepsilon$

First of all, it is important to establish a well-grounded economic theoretical model explaining the expected relationship between the latent variable and the observed variables. The MIMIC model tests this economic theory and confirms the hypothesized relationships between the latent variable $\eta$ (shadow economy) and its causes and indicators by examining the consistency of the actual data with the hypothesized relationships. The Maximum Likelihood method (ML) shall be applied to estimate the parameters of the MIMIC model. Then, the time series index of the Egyptian shadow economy is calculated. This time series MIMIC index based on equation (1) is calculated by multiplying the coefficients of the significant causal variables with the respective time series.

It is important to note that in the MIMIC model estimation, we need to fix an indicator variable in the measurement equation (2). This is required in order to have a reference variable to set a measurement scale. Since that the shadow economy is unobserved and thus not directly measured, it is necessary to determine its unit of measurement i.e. as percentage of GDP. The choice of the sign of the reference variable is not arbitrary. Since that the shadow economy is a latent variable, then it is important to define a unit of measurement which is as \% of GDP in order to have a meaningful interpretation of the how big the size of the shadow economy is. 
There must be a theoretical logic behind choosing the reference indicator and its associated sign. The strategy to determine the sign of the coefficient of the reference variable is called, reductio ad absurdum' which is affected by theoretical assumptions. The importance of fixing this variable is to have unit of measurement to estimate the other variables as a function of this scale variable and to make the estimated coefficients more comparable (Dell'Anno et al., 2007). In our estimations, the reference variable is Real GDP index and is set to a value of -1 . To confirm that the associated sign (-1) of our reference variable in our MIMIC specifications is the correct sign, we have replicated the MIMIC specifications in Table 3.1 while normalizing the reference indicator (Real GDP index) to +1 . As a result, the signs of the causal coefficients change while keeping the same absolute values and significance levels. At this point, we, as researchers, have to make sure whether these signs are theoretically accepted and whether they agree with the empirical evidence in the literature of the shadow economy or not. Thus, the choice of normalizing the Real GDP index to -1 or +1 is based on theoretical assumptions of the observed variables. In the specifications mentioned in Table 3.1, if we normalize the reference variable to +1 , the signs of the observed causal variables change to be against the most widely accepted theoretical and empirical evidence in the literature of the shadow economy. This confirms that the choice of -1 is the right sign of the reference variable. Especially that it is rational to expect that the shadow economy absorbs human capital and resources from the official economy leading to negative externalities.

Instead of constraining Real GDP index to -1 as being our reference indicator, we further conducted another estimation while normalizing Money_Growth to +1 and leaving Real GDP index unconstrained in all the MIMIC specifications summarized in Table 3.1. Based on the outcomes, we confirm that the MIMIC results are robust because the observed variables keep the same signs, coefficient values and significance levels. But for interpretation reasons, we normalize the Real GDP index to -1 as being our reference indicator to provide a meaningful interpretation of the shadow economy i.e. as \% of GDP.

The most widely used estimation method for the MIMIC model is the Maximum Likelihood (ML) estimation. ML estimation a) measures how close is the population covariance matrix to the sample covariance matrix and b) finds the values of the parameters that produce the population covariance matrix that is as close as possible to the sample covariance matrix. Our aim is to minimize the distance between the population covariance matrix and the sample 
covariance matrix in order to reach a perfect fit of the model (Schumacker \& Lomax, 2010). There are four important assumptions that need to be met when estimating the MIMIC model:

1. The variables must be multi-normally distributed ${ }^{20}$.

2. The variables must have a linear relationship.

3. The distribution of the residuals must be homoscedastic.

4. Large sample sizes. The sample size should not be less than 50 .

In addition, one must test whether the time-series is stationary or not. A further step based on the outcome of the unit root test, one must test whether the variables (both the causes and the indicators) are co-integrated or not.

The chosen MIMIC model is based on several model fit characteristics. It is important to note that we should not depend solely on the chi-square fit statistic when evaluating the model fit because it is very sensitive to sample size and the multivariate normality assumption (Singh, 2009, Iacobucci, 2010). In addition to the chi-square statistic, we observe the (adjusted) goodness of fit index and other fit indexes that are based on the covariance residuals including the CD, CFI and standardized RMR (SRMR). The SRMR is a good evaluation of whether the researcher's model captures the data because it is not much sensitive to violation of distribution assumptions (Iacobucci, 2010). There is an agreement in the literature that ideally, the researchers report the chi-square statistic along with the degrees of freedom, CFI and the SRMR (Iacobucci, 2010). For a perfect model fit, the chi-square needs to be insignificant ( $p>0.05$ ), the GFI to be closer to 1, the CFI closer to 0.95 and the SRMR closer to 0.09 (Hu and Bentler, 1999). Other fit statistics to evaluate the model include the RMSEA. RMSEA is a popular statistic to evaluate the model fit where a value of zero indicators a perfect fit, yet it is not preferable in case of small sample sizes; i.e. $\mathrm{N} \leq 200$ (Hu and Bentler, 1998). Given the technicality of the RMSEA calculation, the model degrees of freedom and one less than the sample size are in the denominator, therefore the RMSEA value decreases as the sample size increases showing how the RMSEA is influenced by the sample size due to the fact that small sized samples have few degrees of freedom which in return intensifies the RMSEA (Kline, 2011).

\footnotetext{
${ }^{20}$ A multivariate normal distribution means that each variable in the time-series is univariate normally distributed and each pair of the variables demonstrate a bivariate normal distribution. Multivariate normality describes the joint distribution of all the variables in the time-series (Gao et al., 2008).
} 


\section{A1.3 Benchmarking procedure}

Notably, the MIMIC model provides an estimation of a relative evolution of the size of the shadow economy over time; meaning that it only yields ordinal estimates of the size of the shadow economy. Thus, an additional final step is required to calculate the size of the shadow economy in a meaningful way, hence as percentage of GDP. This last step is called a benchmarking step or procedure. In the literature, there is a wide discussion of the different benchmarking procedures to be applied, but there is no agreement on which procedure is superior to the other ${ }^{21}$. The following benchmarking procedure ${ }^{22}$ is applied to calibrate the ordinal estimates into cardinal values and convert this index to \% units (real values). This requires that a prior estimation of the Egyptian shadow economy to be computed. Thus, the exogenous estimation of the relative size of the shadow economy in Egypt used to calibrate the ordinal values is based on our currency demand approach (1976-2013) in the current study.

$$
\eta \mathrm{t}=\frac{\bar{\eta} t}{\bar{\eta} \text { base year }} \eta * \text { base year }
$$

where $\tilde{\eta} t$ denotes the value of the MIMIC index at time $t$ according to the structural equation (1), п̃ base year is the value of the MIMIC index in the base year which is in our model is 2013, $\eta *$ base year is the exogenous (prior) estimation of the size of the shadow economy in Egypt in the base year $(=2013)$ reaching $32 \%$ of GDP extracted from our CDA results.

Based on the application of this benchmarking procedure, we are able to calculate the final estimates of the size of the shadow economy as percentage of GDP for the given period of our study and to reach a trend of the development of the shadow economy in Egypt from 1976 to 2013.

\section{A1.4 Limitations of SEM MIMIC model}

In the literature, there is no consensus on which model to estimate the size of the shadow economy as being better than the other. Like any other econometric model, the MIMIC model face some limitations. In summary, the first limitation is the application of the MIMIC model to small sample sizes and time series analysis due to non-stationarity and non-normality of the time

\footnotetext{
${ }^{21}$ For further details on the different benchmarking procedures, see Schneider and Dell'Anno (2009).

${ }^{22}$ The benchmarking procedure applied in this paper is widely used in the literature (Schneider et al.,2010)
} 
series. Secondly, the choice of the observed variables to be causal or indicator variable. For instance, unemployment rate can be regarded as a causal variable leading to the development of the shadow economy. At the same time, unemployment rate can be regarded as an effect of the existence of the shadow economy in a certain country. Since that the shadow economy is a latent variable, it is challenging when it comes to defining the shadow economy and to make sure that the shadow economy defined is the one being measured by the MIMIC model and not a similar variable. In order to address these two limitations, the researcher needs to firstly clearly provide a detailed and well-explained theoretical background of choosing the observed variables as causal and indicator variables as well as to provide a clear cut definition of the shadow economy that the researcher is intending to measure by the MIMIC model. Another complexity of the MIMIC model is that it only provides an index of the size of the shadow economy, therefore an additional step is needed to be conducted to convert this index to actual values of the shadow economy as \% of GDP (Dell'Anno, 2007; Dell'Anno and Schneider, 2009; Schneider and Williams, 2013). In conclusion, there is no best or commonly accepted method to estimate the size of the shadow economy. Although that each method has its own limitations, the MIMIC model provides the most extensive reflection of the development of the size of the shadow economy over time while considering various causes and indicators and has been widely used in the last few decades. It is important to acknowledge that there is no exact measure of the shadow economy, in all the cases, we intend to measure economic activities that are, by nature, unrecorded. 
Figure A.1: Hypothesized MIMIC path

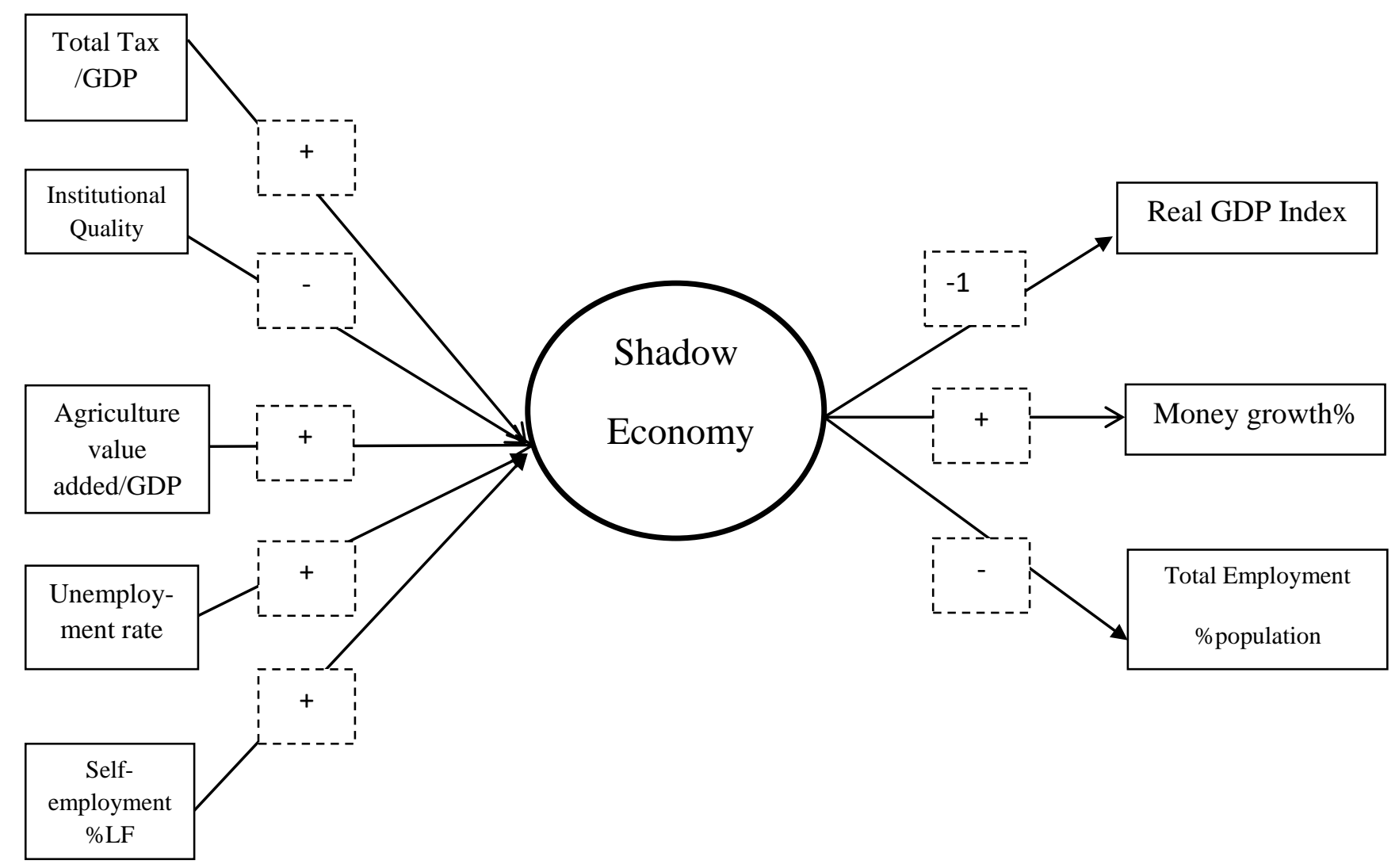

Source: Authors 
Table A.1: ADF Unit root test for CDA variables

\begin{tabular}{|c|c|c|c|c|c|c|}
\hline \multirow[t]{2}{*}{ Variables } & \multicolumn{3}{|c|}{ At level } & \multicolumn{3}{|c|}{ First difference } \\
\hline & Intercept & $\begin{array}{l}\text { Trend and } \\
\text { Intercept }\end{array}$ & $\begin{array}{l}\text { No Trend } \\
\text { and } \\
\text { No } \\
\text { Intercept }\end{array}$ & Intercept & $\begin{array}{l}\text { Trend and } \\
\text { Intercept }\end{array}$ & $\begin{array}{l}\text { No Trend } \\
\text { and No } \\
\text { Intercept }\end{array}$ \\
\hline $\mathrm{C}$ & -0.07 & -0.65 & 1.44 & $-3.44 * *$ & $-3.47 *$ & $-3.07 * * *$ \\
\hline Y/capita & -1.23 & -2.15 & 3.47 & $-5.19 * * *$ & $-5.23 * * *$ & $-3.37 * *$ \\
\hline TAX & -0.98 & -2.14 & -0.65 & $-4.45 * * *$ & $-4.48 * * *$ & $-4.48 * * *$ \\
\hline $\mathrm{R}$ & -1.57 & -2.74 & -0.29 & $-4.85 * * *$ & $-4.40 * * *$ & $-5.08 * * *$ \\
\hline REG & -1.48 & 0.40 & -0.02 & $-3.74 * * *$ & $-4.72 * * *$ & $-3.84 * * *$ \\
\hline SELF & -2.08 & -1.39 & -1.58 & $-7.93 * * *$ & $-8.44 * * *$ & $-7.80 * * *$ \\
\hline GOV & $-3.07 * *$ & -2.27 & $-1.85^{*}$ & $-7.21 * * *$ & $-7.46 * * *$ & $-3.55 * * *$ \\
\hline
\end{tabular}

Reported above are the T-statistics for the Augmented Dicky-Fuller (ADF) test. Null hypothesis: variable has unit root. The lag length was chosen using the Schwarz Information Criterion. *,****** indicate significance at the $10 \%, 5 \%$ and $1 \%$ respectively.

Source: Own calculations 
Table A.2: ADF Unit root test for MIMIC variables

\begin{tabular}{|c|c|c|c|c|c|c|}
\hline \multirow[t]{2}{*}{ Variables } & \multicolumn{3}{|c|}{ At level } & \multicolumn{3}{|c|}{ First difference } \\
\hline & Intercept & $\begin{array}{l}\text { Trend and } \\
\text { Intercept }\end{array}$ & $\begin{array}{l}\text { No Trend } \\
\text { and } \\
\text { No } \\
\text { Intercept }\end{array}$ & Intercept & $\begin{array}{l}\text { Trend and } \\
\text { Intercept }\end{array}$ & $\begin{array}{c}\text { No Trend } \\
\text { and No } \\
\text { Intercept }\end{array}$ \\
\hline $\begin{array}{l}\text { Total_taxes\% } \\
\text { GDP }\end{array}$ & -1.30 & -2.19 & 0.59 & $-5.08 * * *$ & $-5.11 * * *$ & $-5.14 * * *$ \\
\hline $\begin{array}{l}\text { Institutional } \\
\text { Quality }\end{array}$ & -1.41 & -2.06 & -1.14 & $-5.95 * * *$ & $-5.85 * * *$ & $-5.92 * * *$ \\
\hline $\begin{array}{l}\text { Agriculture- } \\
\text { valueadded } \% \\
\text { GDP }\end{array}$ & $-3.04 * *$ & -2.28 & $-3.14 * * *$ & $-4.47 * * *$ & $-4.90 * * *$ & $-4.08 * * *$ \\
\hline $\begin{array}{l}\text { Unemployment } \\
\text { rate }\end{array}$ & -1.28 & -2.23 & 1.46 & $-5.59 * * *$ & $-5.52 * * *$ & $-5.21 * * *$ \\
\hline $\begin{array}{l}\text { Self- } \\
\text { Employment } \\
\% \text { LF }\end{array}$ & -1.93 & -2.35 & -1.48 & $-8.90 * * *$ & $-9.18 * * *$ & $-8.80 * * *$ \\
\hline $\begin{array}{l}\text { Real GDP } \\
\text { index }\end{array}$ & 2.88 & -0.85 & 3.25 & $-2.82 *$ & $-3.41 *$ & -1.03 \\
\hline $\begin{array}{l}\text { Money } \\
\text { growth\% }\end{array}$ & -2.56 & $-3.83 * *$ & -1.12 & $-9.12 * * *$ & $-9.01 * * *$ & $-9.22 * * *$ \\
\hline $\begin{array}{l}\text { Total } \\
\text { emplyoment } \\
\text { \%population }\end{array}$ & -1.45 & -1.83 & 0.68 & $-5.14 * * *$ & $-5.09 * * *$ & $-5.16 * * *$ \\
\hline
\end{tabular}

Reported above are the T-statistics for the Augmented Dicky-Fuller (ADF) test. Null hypothesis: variable has unit root. The lag length was chosen using the Schwarz Information Criterion. *,**,*** indicate significance at the $10 \%, 5 \%$ and $1 \%$ respectively.

Source: Own calculations 
Table A.3: Variables used in the CDA

\begin{tabular}{|c|c|c|}
\hline Variables & Source & Definition \\
\hline Currency in Circulation $\left(\mathrm{C}_{\mathrm{t}}\right)$ & $\begin{array}{l}\text { The series is extracted from the } \\
\text { yearly economic bulletin published } \\
\text { by the Central Bank of Egypt }\end{array}$ & The sum of currency outside banks. \\
\hline GDP per capita (Y/capitat $)$ & World Bank Indicators & $\begin{array}{l}\text { GDP is the sum of gross value added } \\
\text { by all resident producers in the } \\
\text { economy plus any product taxes and } \\
\text { minus any subsidies not included in } \\
\text { the value of the products. It is } \\
\text { calculated without making } \\
\text { deductions for depreciation of } \\
\text { fabricated assets or for depletion and } \\
\text { degradation of natural resources. } \\
\text { GDP per capita is gross domestic } \\
\text { product divided by midyear } \\
\text { population. }\end{array}$ \\
\hline Total tax burden $\left(\mathrm{TAX}_{\mathrm{t}}\right)$ & $\begin{array}{l}\text { The series is extracted from the } \\
\text { yearly economic bulletin published } \\
\text { by the National Bank of Egypt }\end{array}$ & $\begin{array}{l}\text { The total taxes are the total sum in } \\
\text { local currency imposed on income, } \\
\text { profit and sales. }\end{array}$ \\
\hline $\begin{array}{l}\text { Public employment as \% of labor } \\
\text { force }\left(\mathrm{REG}_{\mathrm{t}}\right)\end{array}$ & CAPMAS Labor Sample Survey & $\begin{array}{l}\text { Those who are employed, in the } \\
\text { work force, receive a salary and } \\
\text { characterized according to the type } \\
\text { of sector they are working at. Hence, } \\
\text { the public sector. It is calculated as } \\
\text { a ration to total labour force. }\end{array}$ \\
\hline Self-Employment rate $\left(\mathrm{SELF}_{\mathrm{t}}\right)$ & CAPMAS Labor Sample Survey & $\begin{array}{l}\text { An individual who depends on } \\
\text { himself solely to perform private } \\
\text { business and who does not employ } \\
\text { anyone (with salary or without). The } \\
\text { rat is as } \% \text { of total labour force }\end{array}$ \\
\hline Nominal Deposit Interest rate $\left(\mathrm{R}_{\mathrm{t}}\right)$ & World Bank Indicators & $\begin{array}{l}\text { Deposit interest rate is the rate paid } \\
\text { by commercial or similar banks for } \\
\text { demand, time, or savings deposits. }\end{array}$ \\
\hline
\end{tabular}

Source: Authors 
Table A.4: Variables in the MIMIC model

\begin{tabular}{|c|c|c|}
\hline Variables & Source & Definition \\
\hline $\begin{array}{l}\text { Total taxes in absolute values in } \\
\text { local currency }\end{array}$ & $\begin{array}{l}\text { The series is extracted from the } \\
\text { yearly economic bulletin published } \\
\text { by the National Bank of Egypt }\end{array}$ & $\begin{array}{l}\text { The total taxes are the total sum in } \\
\text { local currency imposed on income, } \\
\text { profit and sales. The burden is } \\
\text { calculated as } \% \text { of GDP. }\end{array}$ \\
\hline $\begin{array}{l}\text { Institutional quality of democratic } \\
\text { institutions (PolityIV index) }\end{array}$ & Polity IV project & $\begin{array}{l}\text { The scale ranges from }-10 \text { to }+10 \text {, } \\
\text { indicating the extent of autocratic to } \\
\text { democratic institutions in a country. } \\
\text { Hence, the higher the index, the } \\
\text { better. }\end{array}$ \\
\hline Unemployment_rate (15+) & $\begin{array}{l}\text { International Labour Organisation } \\
\text { (ILO) }\end{array}$ & $\begin{array}{l}\text { The unemployment rate is the } \\
\text { number of persons who are } \\
\text { unemployed as a percent of the total } \\
\text { number of employed and } \\
\text { unemployed persons (i.e., the labour } \\
\text { force). }\end{array}$ \\
\hline $\begin{array}{l}\text { Agriculture value-added as } \% \text { of } \\
\text { GDP }\end{array}$ & World Bank Indicators & $\begin{array}{l}\text { Agriculture value-added is the net } \\
\text { output of the sector calculated as } \% \\
\text { of GDP. }\end{array}$ \\
\hline Self-Employment rate & CAPMAS Labor Sample Survey & $\begin{array}{l}\text { An individual who depends on } \\
\text { himself solely to perform private } \\
\text { business and who does not employ } \\
\text { anyone (with salary or without). The } \\
\text { rate is calculated as \% of total labour } \\
\text { force }\end{array}$ \\
\hline Real GDP Index & World Bank Indicators & $\begin{array}{l}\text { Index of real GDP, base year } \\
2005=100\end{array}$ \\
\hline Money growth (annual \%) & World Bank Indicators & $\begin{array}{l}\text { Average annual growth rate in } \\
\text { money. Money is the sum of } \\
\text { currency outside banks and demand } \\
\text { deposits. }\end{array}$ \\
\hline Total Employment rate & CAPMAS Labor Sample Survey & $\begin{array}{l}\text { The total number of people who are } \\
\text { formally employed by possessing a } \\
\text { formal contract. The rate is } \\
\text { calculated as } \% \text { of total population. }\end{array}$ \\
\hline
\end{tabular}

\footnotetext{
Source: Authors
} 
Table A.5 Size of the Egyptian shadow economy as \% of GDP (1976-2013)

\begin{tabular}{|c|c|c|}
\hline Year & CDA & MIMIC \\
\hline 1976 & 65.80 & 52.26 \\
\hline 1977 & 58.85 & 51.31 \\
\hline 1978 & 57.28 & 50.61 \\
\hline 1979 & 55.96 & 47.02 \\
\hline 1980 & 54.43 & 48.71 \\
\hline 1981 & 45.70 & 54.29 \\
\hline 1982 & 47.54 & 51.83 \\
\hline 1983 & 45.16 & 51.96 \\
\hline 1984 & 45.92 & 51.15 \\
\hline 1985 & 41.68 & 48.02 \\
\hline 1986 & 34.69 & 48.23 \\
\hline 1987 & 32.79 & 46.30 \\
\hline 1988 & 32.89 & 44.51 \\
\hline 1989 & 32.57 & 44.67 \\
\hline 1990 & 22.66 & 43.95 \\
\hline 1991 & 23.56 & 44.59 \\
\hline 1992 & 21.81 & 43.27 \\
\hline 1993 & 29.29 & 41.97 \\
\hline 1994 & 24.04 & 41.71 \\
\hline 1995 & 23.72 & 41.27 \\
\hline 1996 & 23.98 & 41.10 \\
\hline 1997 & 25.51 & 40.28 \\
\hline 1998 & 26.25 & 41.81 \\
\hline 1999 & 23.56 & 41.95 \\
\hline 2000 & 22.30 & 40.81 \\
\hline 2001 & 20.21 & 40.21 \\
\hline 2002 & 29.00 & 40.62 \\
\hline 2003 & 21.32 & 40.50 \\
\hline 2004 & 22.23 & 39.20 \\
\hline 2005 & 23.82 & 32.05 \\
\hline 2006 & 22.14 & 31.61 \\
\hline 2007 & 31.02 & 31.63 \\
\hline 2008 & 20.38 & 30.90 \\
\hline 2009 & 18.85 & 29.73 \\
\hline 2010 & 25.22 & 29.83 \\
\hline 2011 & 21.84 & 26.78 \\
\hline 2012 & 20.92 & 29.94 \\
\hline 2013 & 32.00 & 32.00 \\
\hline
\end{tabular}

Source: Own calculations 
Table A.7: Stability Analysis

\begin{tabular}{|c|c|c|c|c|c|}
\hline Independent variables & $\begin{array}{c}(1) \\
1980-2013\end{array}$ & $\begin{array}{c}(2) \\
1982-2013\end{array}$ & $\begin{array}{c}(3) \\
1983-2013\end{array}$ & $\begin{array}{c}(4) \\
1985-2013\end{array}$ & $\begin{array}{c}(5) \\
1988-2013\end{array}$ \\
\hline $\mathrm{C}_{\mathrm{t}-1}$ & 1.00 & 1.00 & 1.00 & 1.00 & 1.00 \\
\hline Y/capita $t_{t-1}$ & $\begin{array}{c}2.16 * * * \\
(0.10) \\
{[20.70]}\end{array}$ & $\begin{array}{c}1.32 * * * \\
(0.10) \\
{[12.78]}\end{array}$ & $\begin{array}{c}1.63 * * * \\
(0.23) \\
{[6.88]}\end{array}$ & $\begin{array}{c}0.87 * * * \\
(0.15) \\
{[5.89]}\end{array}$ & $\begin{array}{c}21.13 * * * \\
(2.01) \\
{[10.50]}\end{array}$ \\
\hline $\mathrm{TAX}_{\mathrm{t}-1}$ & $\begin{array}{c}0.50 * * * \\
(0.09) \\
{[5.72]}\end{array}$ & $\begin{array}{c}0.17 * * * \\
(0.06) \\
{[2.71]}\end{array}$ & $\begin{array}{c}0.29 * * * \\
(0.09) \\
{[3.33]}\end{array}$ & $\begin{array}{c}0.05 \\
(0.05) \\
{[1.06]}\end{array}$ & $\begin{array}{c}6.07 * * * \\
(0.98) \\
{[6.18]}\end{array}$ \\
\hline $\mathrm{R}_{\mathrm{t}-1}$ & $\begin{array}{c}-0.19 * * * \\
(0.07) \\
{[2.85]}\end{array}$ & $\begin{array}{c}-0.33 * * * \\
(0.07) \\
{[4.76]}\end{array}$ & $\begin{array}{c}-0.55 * * * \\
(0.16) \\
{[3.40]}\end{array}$ & $\begin{array}{c}-0.75 * * * \\
(0.10) \\
{[7.58]}\end{array}$ & $\begin{array}{c}11.78 * * * \\
(1.32) \\
{[8.95]}\end{array}$ \\
\hline $\mathrm{REG}_{\mathrm{t}-1}$ & $\begin{array}{c}0.03 * * * \\
(0.01) \\
{[3.41]}\end{array}$ & $\begin{array}{c}-0.001 \\
(0.005) \\
{[0.24]}\end{array}$ & $\begin{array}{c}0.02 * * * \\
(0.01) \\
{[3.53]}\end{array}$ & $\begin{array}{c}0.004 \\
(0.003) \\
{[1.25]}\end{array}$ & $\begin{array}{c}0.21 * * * \\
(0.05) \\
{[4.52]}\end{array}$ \\
\hline SELF $_{\mathrm{t}-1}$ & $\begin{array}{c}0.16 \text { *** } \\
(0.01) \\
{[12.71]}\end{array}$ & $\begin{array}{c}0.12 * * * \\
(0.01) \\
{[12.97]}\end{array}$ & $\begin{array}{c}0.15 * * * \\
(0.01) \\
{[12.03]}\end{array}$ & $\begin{array}{c}0.12 * * * \\
(0.005) \\
{[22.37]}\end{array}$ & $\begin{array}{c}0.82 * * * \\
(0.10) \\
{[8.13]}\end{array}$ \\
\hline Cons & $\begin{array}{c}2.63 * * * \\
(1.09) \\
{[2.41]}\end{array}$ & $\begin{array}{c}12.07 * * * \\
(1.12) \\
{[10.80]}\end{array}$ & $\begin{array}{c}8.61 * * * \\
(2.59) \\
{[3.32]}\end{array}$ & $\begin{array}{c}17.15^{* * *} * \\
(1.66) \\
{[10.35]}\end{array}$ & $\begin{array}{c}-213.98 * * * \\
(23.33) \\
{[9.17]}\end{array}$ \\
\hline Log likelihood & 179.12 & 218.51 & 179.94 & 225.03 & 166.83 \\
\hline Autocorrelation LM test & $\begin{array}{c}23.18 \\
\text { Pvalue } \\
0.9514 \\
\end{array}$ & $\begin{array}{l}34.67 \\
\text { Pvalue } \\
53.19 \\
\end{array}$ & $\begin{array}{c}23.99 \\
\text { Pvalue } 0.9372\end{array}$ & $\begin{array}{c}34.94 \\
\text { Pvalue } \\
0.5187 \\
\end{array}$ & $\begin{array}{c}30.61 \\
\text { Pvalue } \\
0.7226 \\
\end{array}$ \\
\hline White test & $\begin{array}{l}309.45 \\
\text { Pvalue } \\
0.2566\end{array}$ & $\begin{array}{l}571.42 \\
\text { Pvalue } \\
0.2184\end{array}$ & Pvalue0.1648 & $\begin{array}{l}567.76 \\
\text { Pvalue } \\
0.2515\end{array}$ & $\begin{array}{l}295.67 \\
\text { Pvalue } \\
0.4617\end{array}$ \\
\hline
\end{tabular}

Source: Own calculations 